\title{
Yeni Bölgesel Gelişme Paradigmalarında Dirençli Mekânlar Olarak Kırsal Alanlar: Beyșehir (Konya) Kırsalı Örneği
}

\section{Rural Areas as Resilience Spaces in New Regional Development Paradigms: A Research in Case of Rural Areas of Beysehir in Konya}

\section{Özer KARAKAYACI ${ }^{1} \oplus$, Firuze KESER ${ }^{2} \oplus$}

${ }^{1}$ Doç. Dr., Konya Teknik Üniversitesi, Şehir ve Bölge Planlama Bölümü, Konya, Türkiye

${ }^{2}$ Yüksek Şehir Plancısı, Kütahya Kültür Varlıklarını Koruma Bölge Kurulu Müdürlüğü, Kütahya, Türkiye

ORCID: Ö.K. 0000-0001-9001-4163; F.K. 0000-0002-4217-9315

\section{Öz}

Bu çalışma yeni bölgesel gelişme paradigmalarında kırsal alanları dirençlilik kavramı üzerinden değerlendirmeyi amaçlamaktadır. Özellikle evrimsel ekonomik coğrafya ile desteklenen kırsal dirençlilik kavramı, bir kırsal alanın geçmişten günümüze kadar gelen süreçte izlediği yol ve olumsuzluklara karşı geliştirdiği yöntemlerin incelenmesi olarak değerlendirilmektedir. Bu çerçevede, paradigma değişimiyle birlikte kırsal alanlara yüklenen yeni anlamı keşfetmek ve bölgesel gelişmenin yeni aktörü olarak kentler lehine baskın olan gelişme dinamiklerinin kırsalda nasıl karşılık bulabileceğine ilişkin örnek alanlar üzerinden değerlendirmeler sunmak çalışmanın temel hedefi olarak belirlenmiştir. Çalışma alanı olarak belirlenen Beyşehir ilçesi kırsalında, kırsal alanda dirençliliği etkileyen faktörler ekonomik, ekolojik ve kültürel bağlamda ele alınarak, paradigma değişimiyle birlikte kırsal alanların yerleşme sistemleri içerisindeki rolü yeniden tartışılmıştır. Niteliksel analiz yöntemlerinin kullanıldığı çalışmada, kırsal dirençlilik kavramı çerçevesinde ele alınan konular, değişkenler ve dinamiklerin kırsal yerleşmeler açısından nasıl bir değer zinciri ortaya çıkaracağına ilişkin bulgular sonraki çalışmalar için yol gösterici nitelikte olacağı düşünülmektedir. Çünkü kırsal dirençlilik bir kırsal bölgenin değişen yaşam standartlarına bağlı olarak dış koşullara uyum sağlama kapasitesi olarak tanımlanırken, kırsal alanın yeni bir yapı ve süreç kümesi etrafında yeniden yapılanmasında değişime tahammül edebilme becerisini belirlemek açısından önemli bir konu olarak görülmektedir. Sonuç olarak, çalışmada yerel beceriler ve yol bağımlılığı gibi unsurlarıyla Beyşehir kırsalının yaşadığı gerileme sürecinin önüne geçilebileceği tespit edilmiştir.

Anahtar kelimeler: Beyşehir, Bölgesel Gelişme, Dirençlilik, Kırsal Alan, Kırsal Coğrafya

\section{ABSTRACT}

This study was aimed at evaluating the concept of resilience to rural areas in the new regional development paradigms. Rural resilience supported by evolutionary economic geography is considered the method developed against the negativity and practices emanating in the past that mired rural areas. The primary goal of this study, according to this framework, is to investigate the new significance that has been accorded to rural regions because of the paradigm shift. Furthermore, the study's major goal has been determined to be to offer assessments on sample areas on how the development dynamics in favor of cities can find resonance in rural areas. The factors affecting resilience are determined according to economic, ecological, and cultural contexts, and the role of rural areas in the settlement systems in the case of Beyşehir are re-discussed. The findings of the study, which employed qualitative analytical methodologies, are expected to provide guidance for future studies on how the challenges highlighted within the framework of the idea of rural resilience will disclose a value chain in terms of rural settlements. Because rural resilience is defined as a rural area's ability to adjust to external situations based on changing living standards, it is more than just the ability to adopt change. Finally, with elements such as local skills and path dependences, it is now possible to prevent the decline of the Beyşehir rural areas.

Keywords: Beyşehir, Regional Development, Resilience, Rural Area, Rural Geography

Başvuru/Submitted: 12.04.2021 • Revizyon Talebi/Revision Requested: 21.09.2021 • Son Revizyon/Last Revision Received: 23.09 .2021 • Kabul/Accepted: 27.12 .2021

Sorumlu yazar/Corresponding author: Özer KARAKAYACI / okarakayaci@ktun.edu.tr

Atıf/Citation: Karakayaci, O., \& Keser, F. (2021). Yeni bölgesel gelişme paradigmalarında dirençli mekânlar olarak kırsal alanlar: Beyşehir (Konya) kırsalı örneği. Cografya Dergisi, 43, 217-233. https://doi.org/10.26650/JGEOG2021-913711 


\section{EXTENDED ABSTRACT}

This study was aimed at evaluating the concept of resilience in rural areas with new regional development paradigms. Rural resilience, which has been discussed in the past decade in evolutionist economic geography, is accepted as the ability to overcome the negativities faced by the local potential of rural areas. The primary goal of this study, according to this framework, is to investigate the new significance accorded to rural regions because of the paradigm shift. Furthermore, the study's major goal has been determined to be to offer assessments on sample areas on how the development dynamics in favor of cities can find resonance in rural areas.

The concept of "resilience," which emerged especially in the ecology literature, was associated with the resistance and resilience approach to be realized by rural areas in the regional planning literature. The concept of "resilience," which means flexibility, resilience, ability to overcome negativities, and a quick recovery period, is used in the process of influencing, and reacting to, external conditions of regions. Among the reasons for including the concept of resilience in regional planning, the literature includes the effects of natural and manmade disasters affecting local communities, the impact of ecology and other sciences, the impact of major problems on the economic environment on different scales, and the policies of public institutions that will affect both local and regional economies.

Rural resilience can be defined as the capacity of a rural area to adapt to external conditions depending on the changing living standards. The concept of rural resilience determines the degree to which a rural area can tolerate change before reorganizing around a new set of structures and processes. The ecosystem of a rural area can be explained by how it can balance economic and cultural functions at the same time. Therefore, the rural resilience perspective is based on the idea that the rural area's own economic, ecological, and cultural systems are increasingly intermingled and that the interactions between these systems increase with intensity and scale. Therefore, rural resilience is based on the interrelation of other types of resilience, such as ecological resilience and cultural resilience. The study's major problem focused on rural resilience. The variables for the analysis were determined in the context of the study's purpose and objectives. To acquire qualitative data on variables, approaches based on documents, observations, focus group interviews, and historical and chronological data were used.

In this study, Beyşehir's rural area, which presents significant differences in terms of rural resilience, was determined as the sample area. Beyşehir has 67 rural settlements. In this study, 24 rural settlements were selected for fieldwork. These settlements were selected for having distinct economic, social, and cultural characteristics or for differing in terms of their economic and demographic structure.

Variables such as path dependency, social capital, diversity, governance, clustering, innovation and competitiveness, and tourist potential are said to be significant in defining a settlement's resilience level. Various subtitles were determined within this framework, and 17 questions were posed in the field study aimed at uncovering the economic and cultural potential of rural villages in Beyşehir. The questions determined for the field study were administered to the rural residents in focus group interviews held in 24 rural settlements, and the answers were recorded. The process of development of rural areas and rural policies in developed and developing countries has been examined. The factors affecting the resilience in the rural areas are determined in the case of the study area in accordance with economic, ecological, and cultural contexts, and the role of rural areas in the settlement systems has been re-discussed. Especially in recent years, in rural areas, issues such as food security, alternative tourism, and counter-urbanization have transformed unrecognizably in places varying in terms of economic activities and demographic characteristics. Thus, in terms of planning, rural areas have been examined, researched, and evaluated as important places for their ability to be considered viable alternative areas for local and regional development strategies. It is the thesis' contribution to the literature on how to construct a value chain on rural settlements through the analysis of variables and dynamics in the context of rural resilience, which will serve as a guide for future research. Because it is crucial toward assessing a rural area's ability to adapt to external conditions based on changing living standards before reorganizing around a new structure and process cluster, rural resilience is defined as a rural area's capacity to adapt to external conditions based on changing living standards.

In this context, bespoke flexible solutions for rural areas need to consider differences in the availability of critical lifelines, infrastructure, community links, and ground connectivity. The Beyşehir rural area's ability to overcome a range of challenges creates the need for more resilient and resilient economic and spatial policies. Finally, it could be said that the decline of the Beyşehir rural area can be prevented with elements such as local skills and path dependences. 


\section{GİRIŞ}

Küreselleşme ve post-modern akımların etkisiyle değişmeye başlayan ekonomik, sosyal, kültürel, mekânsal ve yönetsel yapı etkisini kırsal alanlar üzerinde baskın bir biçimde göstermiştir. Kırsal alanlarda, küreselleşme süreciyle üretim dinamiğinde, kültürel boyutta, demografik yapıda ve aktörlerin sosyal ve politik ilişkileri açısından birçok değişiklikler gözlenmiştir (OrtizGuerrero, 2013). Küreselleşme süreci hızlı kentleşmeye bağlı olarak kırsal alanları hızla göç veren, yoksulluk ve yoksunluk oranının arttığı, doğal kaynakların tükenmeye başladığı, kent-kır arasındaki gelişmişlik farkının gün geçtikçe arttığı alanlar haline getirmiştir. Kırdan kente özellikle genç nüfusun göç etmesiyle birlikte kırsal alanlarda demografik yapı değişmeye başlamış, nüfusu gün geçtikçe azalan kırsal alanlar; yaşlı nüfusu barındıran, eğitim, sağlik vb. kamu hizmetlerinden yoksun alanlara dönüşmüştür. Kırsal alanlar ve kentsel alanlar arasındaki fiziki, sosyal ve ekonomik farkl1lıklar gün geçtikçe artmış, özellikle 20.yy'ın son çeyreğinde artan küreselleşme süreciyle birlikte kırsal alanlardaki sorunlar karmaşık ve çözülemez bir hal almıştır.

Bölgesel ölçekli çalışmalarda, kent ve kırsal arasındaki tartışmaların genellikle kent lehine gerçekleşmesi kırsal alanlara yönelik bilimsel çalışmaların sürekli geride kalmasına neden olmuştur. Özellikle mekânda yaşanan değişim sürecini tanımlayan yeni ekonomik paradigmaların kentsel mekâna yönelik politikaları ve stratejileri (sanayi kümeleri, yenilikçi ve rekabetçi üretim bölgeleri, hizmetler ve servis sektörleri, yönetim merkezleri) üzerine yoğun bir yazın gelişmiş̧en, kırsal alanlarda yaşanan değişim süreci büyük ölçüde göz ardı edilmiştir. Ancak ekonomik ve sosyal yapı karşısında düşük ücret ve katma değerli üretim biçimi ve tarzı, düşük verimlilik ve rekabet gibi zorlukların karşısında, kırsal bölgeler mekânsal, sosyal ve kültürel yerleşik ilişkiler, güçlü sosyal ağlar ve yere-özgü üretim biçimleri, kurumsal zenginlik ve doğal çeşitlilik gibi unsurların etkisiyle bölgesel ekonominin yeni aktörleri olarak ortaya çıkma becerisi beklenmeyen ekonomik şoklara karşı bu potansiyelleri değerlendirebilir. Diğer bir deyişle, yeni ekonomik paradigmalar çerçevesinde bölgesel büyüme için yeni aktörler olarak görülmeye başlanan kırsal alanlar, tarımsal üretim ve gelir, tarımsal rekabet ve ulusal düzeyde gerçekleştirilen teşvikler söyleminden kurtararak rekabetçilik ve yenilikçilik, yerel değerlerin ve kullanılmayan kaynakların değerlendirilmesi, kırsal ekonomilerin çeşitlenmesi ve yerel, ulusal, çok uluslu yönetimler ve STK'ların temel aktör olarak tanımlandığı yönetişim sisteminin tarihsel süreç içerisindeki değişimini ön plana çıkararak bölgesel ekonomiye entegre olmaktadırlar (OECD, 2006). Bu çerçevede kırsala ilişkin yenilikçi yaklaşımlar geliştirilmeye başlanmıştır. Bu süreçte, Mormont (1987) kırsallık kavramını sadece bir alan değil, bir yaşama biçimi olarak ya da çağdaş bir topluma meydan okuyan bir sosyal projeye ilham veren alternatif bir toplum modeli ve toplumsal biçimleri geliştirmek ve mevcut olan ekonomik hayattan daha farklı yaşam biçimini geliştirme alternatifi olarak ele almaktadır (Mormont, 1987'den aktaran; Halfacree, 2006). Kırsallığa yönelik yeni yaklaşımlar ve davranış biçimleri kırsal alanlara yönelik tanımları da kökten değiştirmiștir. $\mathrm{Bu}$ paradigma değișimi neticesinde kırsal alanlar kent merkezleri ile sınırlı ilişkileri olan, ölçek ekonomileri açısından kısıtlı imkânlara sahip, gelir dağılımı çeşitlilik gösteren, kamusal ve özel servis hizmetlerine erişimi kısıtlı olan, tarih, kültür, dil, politik kaygılar, iklim gibi temel özelliklerin yanı sıra, çoklu politik ve kültürel etkileşimin meydana geldiği alanlar ve doğal yapıyla bağlantılı kültürel kodların paylaşıldığı, bölge dışındaki ilişkileri zenginleştiren yerleşme modellerinin geliştiği, ekonomik ve sosyal sistemi çalıştıran kurumsal yapının oluştuğu karmaşık bir yapı olarak tanımlanmıştır (Heijman vd., 2019; Karakayacı, 2018).

Yazında, kırsal alanlara ilişkin bu yeni bakış açıları kentler karşısındaki dezavantajlı konumunun ortadan kalkmasında temel nokta olarak görülmekteyken, ekonomik coğrafya kuramsal arka planından beslenen kırsal dirençlilik kavramı ile son yirmi yılda önemli tartı̧̧malar gündeme gelmiştir (Heijman vd., 2019; Eraydın, 2013; Ortiz-Guerrero, 2013; Halfacree, 2006; OECD, 2006). Evrimci ekonomik coğrafyanın ortaya koyduğu yerleşik/ kökleşmiş ilişkilere sahip yerleşmelerde yörünge bağımlıllı̆ı ve öğrenme bağımlı süreçlerle ortaya çıkan yeni dinamiklerin, başka bölgelerde kopyalanması mümkün olmayan üretim süreçleri ve tarzlarını beslediği kabul edilmektedir (Hassink, vd., 2014). Bu çerçevede, yerleşik ilişkiler açısından büyük birikime sahip kırsal yerleşmeler, kentlerde kopyalanması mümkün olmayan yeni ekonomik mekânları ortaya çıkararak tarihsel arka plana ve ilişkili-ilişkisiz çeşitlenme potansiyelleri ile ön plana çıkmaktadır. $\mathrm{Bu}$ olanaklar, kırsalın kentler karşısındaki avantajları, bölgesel ekonomiye uyumunu kolaylaştıran özellikleri ve ekonomik şoklar karşısında geliştirdiği direnç özelliği olarak görülmektedir (Hassink vd., 2014; Boschma ve Martin, 2010). Bu nedenle çalışmanın kavramsal ve kuramsal çerçevesini dayanıklılık, direnç ve uyum kavramları ve kırsal bölge/mekân tartışmalarıyla birlikte, ekonomik coğrafya yaklaşımları oluşturmuştur. Çalışmada ekonomik coğrafya kavramına vurgu yapılsa da, ekonomik coğrafyanın alt kolu olarak tanımlanan ve ekonomik mekândaki üretim, dağıtım, tüketim gibi süreçleri tarihsel arka plan çerçevesinde ele alan, teknolojik ilerlemenin coğrafyaları, dinamik rekabet avantaj1, ekonomik yeniden yapılanma ve ekonomik büyüme gibi konuları (Boschma ve Martin, 2010) 
inceleyen ve üretim süreçleri açısından birbirlerine yeni bilgiler ve fikirler aktaran, teknolojik olarak ilişkisellik üzerinden değişen ekonomik koşullara uyumu tartışan (Hassink vd., 2014) yaklaşımlar üzerinden değerlendirmeler yapılmıştır.

İlişkisel boyutta kırsal mekânı yeniden ele alan bu yaklaşım, temelde düşük verimlilik ve azalan ekonomik önem karşısında kırsal alanı yeni ekonomik paradigmalar çerçevesinde yeniden keşfetmek, sosyal ve ekonomik sistem içerisinde rolünü yeniden belirleme hedefi üzerine odaklanmıştır (Heijman vd., 2019). Kırsal coğrafyaya yönelik gelişen bu yeni sosyal, politik ve mekânsal yaklaşımlar üretim süreçlerinde yeni etkileşimler, stratejiler ve pratikleri ortaya koyarken, yeni kırsal coğrafyada kurumsal yeniden yapılanmaya yönelik ihtiyaçlar gündeme gelmiştir (McDonagh, 2013). Kırsal bölgeler bu tartışmalar bağlamında bilgi, beceri, yetenekleri içerisinde barındıran ve yere özgü nedensel ilişkileri derinlemesine ele alan dinamik bir yapı içerisinde tanımlanmıştır. Bu yaklaşım mekânsal parçaları birbirinden ayıran ve mekâna teklik özelliği kazandıran unsurlar üzerinden üretim organizasyonunu yenilemekte ve bölgesel gelişmeyi hedeflemektedir. Ley (1978)'in yere ilişkin aktörler arasında oluşan müzakerelerin ortaya çıkaracağı sonuçların sosyal olarak oluştuğu ve aktörlerin yerel kimliklerinin nasıl güçlendirildiği üzerine yapılan çalışmalarında aslında yerin ilişkisel nedenlerinin derinlemesine ele alındığı, bir başka deyişle sosyal sermaye unsurları bağlamında yerin ilişki ağlarının ortaya çıktığı görülmüştür. $\mathrm{Bu}$ çerçevede, kırsal sosyal bilimciler değişim ve sürekliliğin sonuçlarını evrimsel ekonomik coğrafya başlığı altında "seçim ve adaptasyon", "yola bağımlılık" gibi kavramlarla mekân ekonomilerinin gelişimini anlamada tarih ve coğrafyanın önemine vurgu yapmaktadırlar (Tonts vd., 2014). Pike vd. (2010) göre; dirençlilik düşüncesinde üç boyut söz konusudur. Birincisi, yol bağımlılı̆̆ının tarihsel boyutunun "şokların" değişim süreçleriyle yakından ilişkili olmasıdır. İkincisi, teknolojik gelişmelerin hızlandırılması, dış kaynakların içe aktarılması ve ekonomik faaliyetlerin çeşitlendirilmesi ile bölgenin uyum kapasitesinin artırılarak bölgesel kilitlerin çözülmesidir. Üçüncüsü ise bölgesel ekonomik kalkınma yollarının neden ve nasıl ortaya çıktığını daha iyi anlamak için süreklilik kavramı yerine değişim kavramına öncelik verilmesidir.

Kırsal alanlar yeni ekonomik ve sosyal paradigmalarla birlikte doğal ve kültürel yapısını koruyan, çeşitlendirilmiş ekonomik faaliyetleriyle rekabet edebilirliğini artırmış, taleplere cevap verebilir bir mekâna dönüşme eğilimi içerisine girmiştir. Litertürde üçüncü yolcular olarak tanımlanan yeni bölgeselci paradigmalar, kırsal alanları daha çok yenilikçilik, bölgesel yenilikçi sistem, kümelenme, bilgi ve öğrenme ekonomisi, kültürel ekonomi, cinsiyet, ağlar, dinlenme ve sosyal sermaye gibi kavramlar üzerinden ele almaya başlamıştır. Yeni bölgeci paradigmaların kırsal bölgeleri yeniden göz önünde bulundurmasıyla birlikte kırsal alanlar doğal üretim kaynaklarının kullanıldığı, yüz yüze ilişkilerin yoğun olduğu, geleneklere ve göreneklere bağlı yaşam biçiminin hâkim, ekonomik, toplumsal ve kültürel gelişmelerin yavaş olduğu mekânlar olarak gelişmeyi tetikleyecek potansiyele sahip değilken, yerel değerlerin kullanımı ve kullanılmayan kaynakları tetikleyecek yere özgü sosyo-iktisadi ve sosyo-kültürel ağırlıkların yeni kurumsal çerçevede değerlendirilmesiyle bölgesel kalkınmanın en önemli hedefi haline gelmiştir (Karakayacı, 2018).

Yeni Bölgeselcilik yaklaşımları, kırsal alanları karmaşık mekânlar olarak birbirleriyle işbirliği içinde olan 4 boyutta ele almıştır. Bunlar, çoklu kültürel politik ve kültürel etkileşimin meydana geldiği bölge/alan; geçim kaynağı olarak doğal kaynak ve alanlarla bağlantılı özgün kültürel yapının paylaşıldığı bir nüfus; insan, ürün ve bilgi değişimi sayesinde dışsal ilişkilerini geliştirdiği yerleşim/yerleşme ve son olarak tüm sistemi çalıştıracak olan kamusal ve özel kurumlardır (Perez, 2001; aktaran: Ortiz-Guerrero, 2013). Yeni Bölgeselcilik yaklaşımları, kırsal alanları sadece tarımsal üretim ve rekabet, ulusal teşvikler gibi konulardan uzaklaştırarak yerel değerlerin ve kaynakların kullanılarak çeşitlilik, rekabetçilik ve yenilikçilik gibi kavramlarla bölgesel büyüme için ele alınabileceğini savunmaktadır. Ekonomik coğrafya literatüründe sıklıkla karşılaşılan yol bağımlılığı, örgütsel rutinler, birikim, bölgesel kilitlenme, kümelenme, yığılma ekonomileri, yenilikçilik, çeşitlilik, sosyal sermaye gibi kavramlar yeni bölgeselcilik bakış açısıyla tekrar değerlendirilmeye başlanmıştır.

Yeni Bölgeselcilik yaklaşımlarında kırsal alanların belirli coğrafik sınırları olan bir mekân olarak mı yoksa yaşam biçimi, toplumsal ilgi ve beklentiler, kültürel yapı ve girişimcilik kavramlarıla birlikte tanımlanan sosyal bir çevre olarak $\mathrm{m} ı$ alınması gerektiği ana tartışma konularındandır (Halfacree ve Boyle, 1998'den aktaran Karakayac1, 2018). Kırsal alanlar teknolojik gelişmelerin mekânı değiş̧irmesi ve karşılıklı ilişkilerle birlikte yeniliklere neden olmasından dolayı yerelleşmiş beceriler, gömülülük, yönetişim, yığılma gibi konuları ele alan kurumsalcı bakış açısıyla ilişkilendirilebilir. Bu bakış açısında kırsal alanların tarihi ve kültürel özelliklerinin gerektirdiği alışkanlıkları temel alarak sorunların çözümlenebileceği savunulmaktadır.

Diğer taraftan kırsaldaki değişim ve dönüşüm süreçlerinin toplumsal ilişkiler, pazara ulaşım olanaklarının artırılması, süreç ve aktörler; kırsal alanların tüketim ve üretim yeri haline gelmesinde göz önünde bulundurulması gereken faktörler (McDonagh, 2013) 
üzerindeki etkiler ile küreselleşmeye yapılan vurgunun gün geçtikçe artmasıyla birlikte, kırsal alanların bölge ekonomileri üzerindeki rolü daha fazla ilgi uyandırmıştır. Dolayısıyla, kırsal ekonominin zayıf rekabetçi yapısı küresel düzlemde dezavantajlı bir durum olarak görülürken, yerele özgü ve kopyalanması mümkün olmayan ekonomik faaliyetleri ön plana çıkaran yapısı bölgesel ekonomi içerisinde yeniden değerlendirilmeyi zorunlu kılmıştır. Bu süreçte, kırsalın özellikle zayıf rekabetçi yapının sunduğu dezavantajların nasıl diğer özellikleri ile bertaraf edilebileceğine ilişkin yazında önemli tartışmalar yapılmıştır. Bu çerçevede özellikle ekoloji odaklı literatürde ortaya çıkan "resilience" kavramı, bölge planlama literatüründe kırsalın gerçekleştireceği direnç ve dayanıklılık yaklaşımıyla ilişkilendirilerek bölgesel ekonomideki etkisi tartışılmıştır. Dayanıklılık, esneklik, dirençlilik, olumsuzlukları yenebilme ve çabuk iyileşme anlamlarına gelen "resilience" kavramı kentlerin ve bölgelerin dış koşullardan etkilenme ve tepki verme sürecinde kullanılmaktadır (Eraydın, 2013). Dirençlilik kavramının bölge planlama literatürüne girmesinin nedenleri arasında; yerel toplulukları etkileyen doğal ve insan kaynaklı felaketlerin etkisi, ekoloji ve diğer bilimlerin etkisi, büyük sorunların farklı ölçekteki ekonomik ortamı etkilemesi ve kamu kurumlarının hem yerel hem bölgesel ekonomileri etkileyecek olan politikaları sayılabilir.

Kırsal dirençlilik, bir kırsal bölgenin değişen yaşam standartlarına bağlı olarak diş koşullara uyum sağlama kapasitesi olarak tanımlanabilir. Kırsal dirençlilik kavramı belirli bir kırsal alanın yeni bir yapı ve süreç kümesi etrafında yeniden örgütlenmeden önce değişime tahammül edebilme derecesini belirler. Bir kırsal alanın ekosistemi, ekonomik ve kültürel işlevleri aynı anda nasıl dengeleyebileceğiyle açıklanabilir. Şekil 1'de görülebileceği gibi, kırsal dirençlilik kırsal alanın kendi ekonomik, ekolojik ve kültürel sistemlerinin giderek birbirine karıştığ fikrine dayanır ve bu sistemler arasındaki etkileşimler yoğunluk ve ölçeğe göre artmaktadır. Kırsal dirençlilik ekolojik

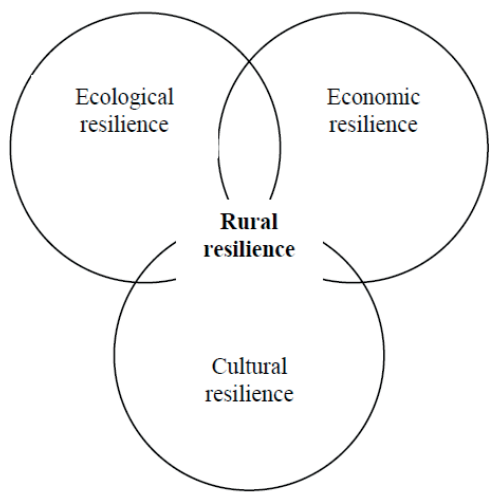

Şekil 1: Kırsal dirençlilik unsurları ve boyutları (Heijman vd., 2019). Figure 1: Elements and dimensions of rural resilience. dayanıklılık ve kültürel dirençlilik gibi diğer dirençlilik türlerinin karşılıklı ilişkisine dayanır (Heijman vd., 2019).

\section{METODOLOJI}

$\mathrm{Bu}$ çalışma kırsal alanların bölgesel ekonomik gelişme süreçlerine uyum sağlayabilme becerisi ile kentler karşısındaki dezavantajlı konumunun giderilmesine yönelik potansiyelleri keşfetmeyi hedeflemektedir. Bu çerçevede, çalışma alanı olarak sosyo-ekonomik, sosyo-kültürel ve sosyo-mekânsal özellikler açısından karşılaşabileceği şoklara karşı direnç gösterme dinamiklerine sahip Konya ili, Beyşehir ilçesi kırsal alanı seçilmiştir. Beyşehir kırsalının çalışma alanı olarak belirlenmesinin dört nedeni vardır: [1] Beyşehir ilçesinin tarihi dönemde önemli ticaret yollarının üzerinde bulunması, [2] coğrafi özellikleri ve kaynaklarının (Beyşehir Gölü’ne sahip olması) kırsal yerleşmelerde temel geçim kaynağı olan tarımsal faaliyetlerde çeşitlilik (meyve, sebze, tahılgiller üretimi) sağlaması, [3] bölgenin tarımın yanı sıra önemli ekonomik faaliyetlere (balıkçılık, av tüfeği üretimi, sucuk imalathaneleri ve cips, tekstil ve mermer fabrikaları) sahip olması, [4] tarihi ve kültürel yapıların yanı sıra doğal güzellikleri sayesinde önemli turizm potansiyelinin varlığı. Bu özellikler Beyşehir bölgesinde yere özgü üretim kültürü ve örtük değerlerin yerleşik potansiyelinin varlığını somut olarak ortaya koymaktadır. Diğer taraftan, Beyşehir kırsalının bu potansiyellerine karşın ekonomik ve sosyal açıdan yeterli gelişme dinamiklerini tamamlamamış olması, Beyşehir kırsalında gelişmişlik farkının önemli dengesizlikler içermesi gibi nedenler bölgenin örnek alan olarak belirlenmesinde etkili olmuştur.

Yukarıda belirtildiği üzere kentler lehine gelişme dinamiklerinin baskın olduğu ve özellikle mekânda yaşanan değişim sürecini tanımlayan yeni liberal ekonomik paradigmaların kentsel mekâna yönelik politikaları ve stratejilerine yönelik yoğun bir yazın söz konusudur. Bu çerçevede, çalışmanın temel amacı tarımsal üretim ve gelir, tarımsal rekabet ve ulusal düzeyde gerçekleştirilen teşvikler gibi söylemlerin ötesinde rekabetçilik ve yenilikçilik, yerel değerlerin ve kullanılmayan kaynakların değerlendirilmesi, kırsal ekonomilerin çeşitlenmesi ve yerel, ulusal, çok uluslu yönetimler ve STK'ların temel aktör olarak tanımlandığı yönetişim sisteminin ön plana çıkartıldığı ve tarihsel olarak elde edilen birikimin ekonomik-sosyal gelişme üzerinde baskın olduğu kırsal bölgelerin bölgesel ekonomiye uyumu sürecine gösterdiği direnç düzeyini keşfetmek ve bu çerçevede kırsal alanları yeniden keşfetmektir.

Bir kırsal yerleşme ekonomik yönden dayanıklı olmazsa, gelir yönünden azalma ve iş güvensizliği artacak; bu durum kırsal 
göçün artmasıyla savunmasız bölgeler ortaya çıkmasına neden olacaktır. Ekolojik yönden dirençli olmayan kırsal alanların, tarım ve yeşil hizmet koşullarının bozulmasıyla kırılganlığı artacaktır. Kırsal sürdürülebilirlik ve kırsal dirençlilik ileriye yönelik olduğundan dolayı sistemin dirençliliği sürdürülebilirliğin önemli bir unsuru olarak incelenebilir. Çeşitlilik ve dirençlilik arasında da benzer bir bağlantı söz konusudur. Konuyla ilgili yapılan birçok araştırma, tür zenginliğindeki artışın ekosistemin toplam üretkenliği, istikrarı ve çevresel değişiklikler karşısında dayanıklılığında bir artış meydana geldiğini göstermektedir. Kültürel dirençlilik bölgedeki beşeri sermayesinin varlığını garanti altına aldığından kırsal dirençlilik için gerekli bir koşuldur. $\mathrm{Bu}$ nedenle azalan bir kültürel dirençlilik kırsal sistemin savunmasızlığına katkıda bulunmaktadır (Heijman vd., 2019). Kırsal alanların bu sorunlarına cevap verebilen ve ekonomik büyüme, sosyal uyum ve çevresel sürdürülebilirliği sağlayan kalkınma dinamikleri başarılı olarak görülmektedir. Olumlu sonuçlar alınan kırsal yerleşmelerde kırsal dinamiklerin kırsal nüfusu koruduğu, sakinlerin yaşam kalitesini iyileştirdiği (sosyal ve ekonomik sermaye) ve çevresel sürdürülebilirliği sağladığ anlaşılmaktadır (Sánchez-Zamora vd., 2014). Bu kavramsal çerçeve bağlamında, çalışmanın amacı ve hedefleri bağlamında analize yönelik değişkenler belirlenmiştir. Değişkenlere ilişkin verilerin elde edilmesinde dokümanlar, gözlem, odak grup görüşmeleri, tarihsel ve kronolojik verilere dayalı yöntemler kullanılarak nitel veriler elde edilmiş̧ir.

Alan çalışması öncesinde Beyşehir ilçesine yönelik yapılan araştırmalar sonucunda odak grup görüşmesi yapılması gereken kırsal yerleşmeler belirlenmiş̧ir. Kırsal yerleşmeler nüfus gruplaması yapıldıktan sonra, yapılan kaynak araştırması sonucunda, belirgin ekonomik, sosyal ve kültürel özelliklere sahip ya da ekonomik ve demografik yapısı açısından değişkenlik gösteren yerleşmelerden seçilmiştir. Toplam 67 kırsal yerleşmesi bulunan Beyşehir ilçesinde 24 kırsal yerleşmede grup odak görüşmesi gerçekleştirilmiştir. Tablo 1'de görüleceği üzere,

Tablo 1: Derinlemesine görüşme yapılan kırsal yerleşmeler.

Table 1: Rural settlements in which in-depth interviews were made.

\begin{tabular}{|c|c|c|}
\hline Nüfusu & Adı & Seçilme Nedeni \\
\hline \multirow{7}{*}{$0-250$} & Yunuslar & $\begin{array}{l}\text { Konya-Beyşehir karayoluna yakın konumda bulunması } \\
\text { Dere yatağı yakınında kurulmuş olması }\end{array}$ \\
\hline & İsaköy & Konya-Beyşehir karayoluna yakın konumda bulunması \\
\hline & Eylikler & $\begin{array}{l}\text { Konya-Beyşehir karayoluna yakın konumda bulunması } \\
\text { Beyşehir ilçe merkezine yakın konumda bulunması }\end{array}$ \\
\hline & Küçükavşar & Beyşehir ilçe merkezine yakın konumda bulunması \\
\hline & Hüseyinler & Beyşehir ilçe merkezine uzak konumda bulunması \\
\hline & Fasıllar & $\begin{array}{l}\text { Beyşehir ilçe merkezine uzak konumda bulunması } \\
\text { Kayalık ve engebeli bir bölgede kurulmuş olması } \\
\text { Fasıllar Anıtı'nın bulunması }\end{array}$ \\
\hline & Mesutlar & Beyşehir ilçe merkezine uzak konumda bulunması \\
\hline \multirow{6}{*}{$250-500$} & Adaköy & Önemli su kaynakları yakınında kurulmuş olması \\
\hline & Damlapınar & Dere yatağı yakınında kurulmuş olması \\
\hline & Karahisar & Kayalık ve engebeli bir bölgede kurulmuş olması \\
\hline & Emen & $\begin{array}{l}\text { Konya-Beyşehir karayoluna yakın konumda bulunması } \\
\text { Ovalık alan üzerinde kurulmuş olması }\end{array}$ \\
\hline & Üçpınar & $\begin{array}{l}\text { Konya-Beyşehir karayoluna yakın konumda bulunması } \\
\text { Dere yatağı yakınında kurulmuş olması }\end{array}$ \\
\hline & Gölkaşı & $\begin{array}{l}\text { Beyşehir Gölü yakınında yer alması } \\
\text { Eski Milli Park sınırı içinde yer alması }\end{array}$ \\
\hline \multirow{4}{*}{$500-750$} & Kurucuova & $\begin{array}{l}\text { Tarihsel dönem içinde yangın felaketi yaşamış olması } \\
\text { Eski Milli Park sınırı içinde yer alması }\end{array}$ \\
\hline & Bayşavşar & Farklı üretim tesislerinin bulunması \\
\hline & Üstünler & Beyşehir-Derebucak karayoluna yakın konumda bulunması \\
\hline & Gölyaka & $\begin{array}{l}\text { Beyşehir Gölü yakınında yer alması } \\
\text { Eski Milli Park sınırları içinde yer alması } \\
\text { Kubad-Abad Sarayı'nın bulunması }\end{array}$ \\
\hline $750-1000$ & Akçabelen & Coğrafi işarete sahip ürününün bulunması \\
\hline \multirow{6}{*}{$1000-2500$} & Doğanbey & Dağ eteği ovasında yer alması ve sucuk üretim tesislerinin varlığı \\
\hline & Esence & $\begin{array}{l}\text { Ovalık alan üzerinde kurulmuş olması } \\
\text { İki önemli karayolu arasında yer alması }\end{array}$ \\
\hline & Sadıkhacı & $\begin{array}{l}\text { Eflatunpınar Anıtı'nın bulunması } \\
\text { Ovalık alanda kurulmuş olması }\end{array}$ \\
\hline & Yeşildağ & Eski Milli Park sınırı içinde yer alması \\
\hline & Huğlu & Av tüfeği üretim tesislerinin varlığı \\
\hline & Bademli & Beyşehir ilçe merkezine yakın konumda bulunması \\
\hline
\end{tabular}


odak grup görüşmeleri gerçekleştirilen kırsal yerleşmeler nüfus büyüklükleri, coğrafik dağılımları, ekonomik ve kültürel özellikleri dikkate alınarak seçilmiştir. Alan çalışması 2019 yılının Eylül-Kasım ayları arasında yazarlar tarafından birebir gerçekleştirilmiştir.

$\mathrm{Bu}$ çerçevede, Beyşehir kırsalının dirençlilik düzeyine ilişkin değişkenlerin ve bu değişkenlere ilişkin verilerin elde edilmesine yönelik toplam 17 soru belirlenmiştir. Tablo 2'de görüleceği üzere bu sorular kültürel dirençlilik, ekonomik dirençlilik ve ekolojik dirençlilik kategorisinde belirlenmiştir.

Görüşmeler esnasında alınan yazılı notlar, literatür taramasıyla desteklenerek raporlanmıştır. Ekolojik dayanıklılı̆ga ilişkin veriler; makaleler, doktora tezleri, ilçe raporları, ilgili kurum raporları ve analizlerinin yanı sıra alan çalışması sırasında yapılan gözlemler ve çekilen fotoğraflardan elde edilmiştir. Çalışmada, Beyşehir kırsalı morfolojik özellikler ve ekonomiksosyal yapı açısından üç bölgeye ayrılarak karşılaştırmalı analizler yapılmıştır (Şekil 2).

Beyşehir kırsalı özelinde belirlenen üç bölgenin ekonomik, kültürel ve ekolojik açıdan dirençlilik düzeyi değişkenin bölge için avantajlı olması durumunda "+1", belirleyici bir değişken olmaması durumunda " 0 ", dezavantajlı bir durum söz konusu olduğunda ise "-1" olarak puanlanmıştır. Tüm değişkenler özelinde elde edilen puanların toplamı, bölgelerin dirençlilik

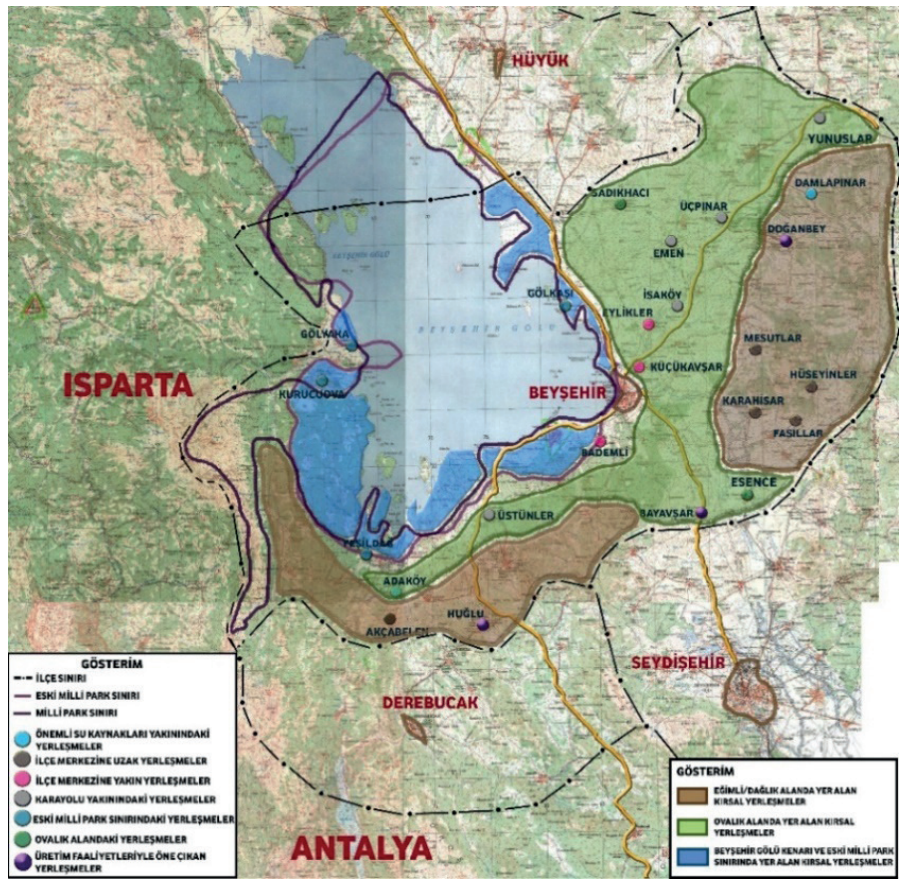

Şekil 2: Morfolojik özelliklerine göre gruplandırılarak görüşme yapılan kırsal yerleşmeler.

Figure 2: Rural settlements grouped according to their morphological characteristics for in-depth interviews.

düzeyini ortaya koymaktadır (Tablo 3). Diğer taraftan, grup odak görüşmeleri neticesinde elde edilen veriler üzerinden bölgenin kültürel, ekonomik ve ekolojik dirençlilik düzeyine ilişkin niteliksel değerlendirmeler yapma olanağı sunmuştur.

Tablo 2: Beyşehir kırsalı dirençlilik değişkenleri.

Table 2: The resilience variables for Beyşehir rural areas.

Çevredeki kırsal yerleşmelerle ilişkisi nasıldır? (Akrabalık, husumet, ekonomik vb.)

Kırda çeşitli örgütlenme faaliyetleri var mı? Amacı nedir? (Dernek, vakıf, oda vb.)

Mahallenizle ilgili alınması gereken kararlarda halk katııımı sağlanıyor mu?

Siz neden burada yaşıyorsunuz, sizi bağlayan temel unsurlar nelerdir?

Kültürel Dirençlilik ile ilişkiniz ne düzeydedir?

Geçmişten günümüze devam ettirdiğiniz toplumsal gelenek-görenekler nelerdir? (festival, vb.)

Unutulmaya yüz tutmuş ve desteklenmesi gereken el sanatlarınız veya üretim teknikleriniz nelerdir?

Yerel halk turizmin gelişmesine katkı sağlayabilir mi? Kırsal turizmi ön plana çıkarabilecek mimari, sosyal veya ekonomik alışkanlıklarınız nelerdir?

Geleneksel üretim tekniklerinizin başlangıcı nasıl olmuştur, kabiliyet ve geleneğin temeli nereye dayanmaktadır? Beyşehir ilçe merkezi ile ilişkiniz nedir? Hangi amaçla, ne kadar sıklıkla ve hangi araçlarla gidilir?

Geçmişten günümüze gelen üretim ve yaşam alışkanlıklarınızın ekonomik gücünüzü belirlemedeki rolü nedir?

Yerel veya ulusal pazara açılmış üretiminiz nedir? Arz ve talep karşılanabiliyor mu?

Mahallenizde ekonomik gelir kaynakları nelerdir? Özellikle desteklenmesi gereken ekonomik sektör nedir?

Ekonomik faaliyetler arasındaki ilişki nasıl? Üretim yapılan ürün üzerinde sektörleşmeler var mı? (Paketlenmesi, dağıtımı vb. nasıl yapılmaktadır)

Eğer imkânınız olsaydı mahallenizdeki hangi ekonomik gelir üzerine ne tür yatırım yapardınız? Mahallenizin hangi potansiyelinin desteklenmesini isterdiniz?

Köylünüz olup önemli işadamı, siyasetçi vb. kişiler var mı? Mahallenize herhangi bir yardımda bulunup yatırım yapıyorlar mı? Yerel yönetim aktörleri arasındaki ilişkiniz nedir? Mahallenize yapılan proje var mı?

Morfolojik özellikler

Ekolojik Dirençlilik İklimsel özellikler

Koruma bölgeleri

Arazi kullanım kabiliyeti 
Tablo 3: Değişkenlere göre dirençlilik düzeylerinin belirlenmesi.

Table 3: Determination of the resilience levels according to the variables.

\begin{tabular}{|c|c|}
\hline Dirençlilik & Değişkenler \\
\hline \multirow[t]{2}{*}{ Ekolojik Dirençlilik } & Arazi yapısının ekonomik faaliyetler açısından uygunluk düzeyi \\
\hline & Ekonomik faaliyetler açısından iklim çeşitliliği ve olanağı \\
\hline Uygun: 1 & Koruma statüleri açısından ortaya çıkan engeller ya da kısıtlar \\
\hline Orta Düzeyde: 0 Uygun Değil: -1 & Arazi kullanım biçimleri ve çeşitliliğinin avantajları \\
\hline \multirow[t]{2}{*}{ Ekonomik Dirençlilik } & Kırsal yerleşmenin Beyşehir ilçe merkezine erişilebilirlik düzeyi \\
\hline & Yerleşmenin geçmişten günümüze gelen üretim ve yaşam alışkanlıklarının ekonomik yapının gelişmedeki rolü \\
\hline Yüksek: 1 & Yerel veya ulusal pazara açılmış üretiminizin çeşitliliği \\
\hline Orta: 0 & Yerleşmede desteklenmesi gereken ekonomik faaliyet çeşitliliği \\
\hline \multirow[t]{4}{*}{ Düşük: -1 } & Ekonomik faaliyetlerdeki uzmanlaşma düzeyi \\
\hline & Yerleşmede ekonomik açıdan desteklenmesini önemli gördüğünüz ekonomik faaliyetlerin türü ve rolü ne düzeydedir \\
\hline & Bölge dışındaki hemşerilerinizin ekonomik gelişme adına sağladığı katkıların düzeyi \\
\hline & Yerel ve merkezi yönetimlerin yatırım kapasitesi \\
\hline \multirow[t]{2}{*}{ Kültürel Dirençlilik } & Çevredeki kırsal yerleşmelerle kültürel ilişkilerin düzeyi \\
\hline & Yerleşmede kültürel faaliyetlerin devamını sağlayacak örgütlenme düzeyi nedir \\
\hline Yüksek: 1 & Yerleşmeniz ile ilgili alınması gereken kararlarda halk katılımı düzeyi \\
\hline Orta: 0 & Yerleşmeye bağımlılık düzeyiniz \\
\hline \multirow[t]{5}{*}{ Düşük: -1 } & Bölge dışından gelenlerin yerleşmeye olan ilgi düzeyi \\
\hline & Geçmişten günümüze devam ettirdiğiniz toplumsal gelenek-göreneklerin yoğunluğu \\
\hline & Unutulmaya yüz tutmuş ve desteklenmesi gereken el sanatlarının çeşitliliği \\
\hline & Kırsal turizmi ön plana çıkarabilecek mimari, yapı ve sosyal çeşitlilik düzeyi \\
\hline & Geleneksel üretim teknikleri ve kabiliyetin düzeyi \\
\hline
\end{tabular}

\section{ARAŞTIRMA BULGULARI}

\subsection{Beyșehir Kırsalı}

Akdeniz ve İç Anadolu Bölgeleri arasındaki geçişi sağlayan önemli yollar üzerinde yer aldığından dolayı tarih boyunca birçok yerleşime ev sahipliği yapan Beyşehir, 1928 yılında ilçe olmuştur. Kırsal nüfus dağılımında topoğrafya, iklim, bitki örtüsü ve ekonomik faaliyetlerin etkili olduğu Beyşehir ilçesinde; su kaynaklarına yakın bölgelerde, düzlük alanlarda ve önemli yol akslarının geçtiği (Konya-Beyşehir, Beyşehir-Isparta, Beyşehir-Derebucak) alanlarda nüfusun yüksek olduğu kırsal yerleşmeler bulunmaktadır.

Su kaynaklarına yakın ve coğrafi açıdan uygun alanlarda (ova, dağ eteği ovası) kurulmuş kırsal yerleşmelerin ekonomik gelirlerinin temelini tarım oluştururken, coğrafi açıdan çeşitli kısıtlamalara maruz kalan kırsal yerleşmelerin (orman alanlarının yoğun olduğu, dağlık ve engebeli alanlarda kurulan) ekonomik gelirlerihayvancılık ve diğersektörlerüzerindeyoğunlaşmaktadır. Göl çevresindeki kırsal yerleşmelerde balıkçılık faaliyetleri de görülmektedir. Beyşehir kırsalının büyük bir bölümünde halı ve kilim dokumacılığının genç nüfusun özellikle büyükşehirlere göç etmesiyle birlikte unutulan geleneksel üretim biçimi olduğu söylenebilir. 6360 sayılı Kanun öncesinde 18 belde ve 37 köy tüzel kişiliği bulunan Beyşehir ilçesinde toplamda 67 mahalle bulunmaktadır. Şekil 3'te bu mahallelerin nüfus büyüklükleri şematize edilmiştir. Gölyaka, Kurucuova, Yeşildağ, Adaköy,
Akçabelen, Huğlu, Kayabaşı, Üzümlü, Üstünler, Gökçimen, Bayavşar, Esence, Doğanbey, Sadıkhacı, Emen, Sevindik, Yenidoğan, Karaali Mahalleleri 6360 sayılı Kanun öncesinde belde statüsünde olan yerleşmeler iken, 6360 Sayılı Kanun’la birlikte mahalle statüsüne geçmiştir.

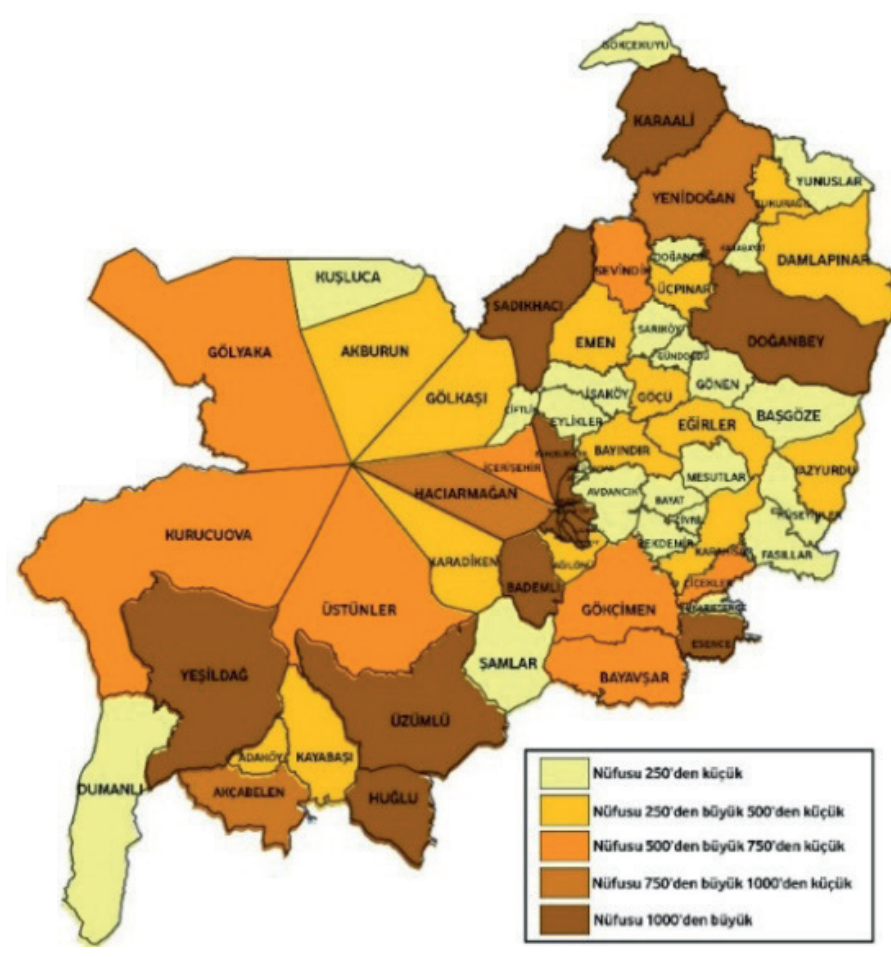

Şekil 3: Beyşehir kırsal yerleşmeleri nüfus büyüklükleri. Figure 3: Population sizes of rural settlements in Beyşehir. 
Beyşehir kırsalı tarımsal üretim faaliyetleri açısından yoğun bir bölge olmakla birlikte, taş kömürü madenciliği, boksit ve krom madenciliği, mermer ve traverten ocakları, çakıl ve kum ocakları gibi taşa ve toprağa dayalı ekonomik faaliyetlerin yoğun bir biçimde gerçekleştiği yerleşmeler mevcuttur. Yanı sıra, bölgede tekstil ürünleri imalatı, cips üretimi ve balık ürünlerinin işlenmesi gibi faaliyetler söz konusudur (MEVKA, 2014). Beyşehir ilçesine bağlı Huğlu ve Üzümlü kırsallarında yoğunlukla gerçekleştirilen av tüfeği imalatı ise, bu ölçekte benzerine rastlanılması oldukça zor bir ekonomik faaliyet olarak ön plana çıkmaktadır. Beyşehir'de özellikle Huğlu ve Üzümlü yerleşmeleri Türkiye'deki av tüfeği imalatının \%70'ini karşılamaktadır (MEVKA, 2014). Türkiye'de modern seviyede ilk av tüfekleri üretimi, Huğlu'da 1962 yılında kurulan Huğlu Av Tüfekleri Kooperatifinde kendi adı ile gerçekleştirilmiştir. Yine Doğanbey kırsalından çıkarılan memba suyunun şişelenerek pazarlandığı "Beysu Tesisleri” önemli bir ekonomik faaliyet olarak değerlendirilmektedir.

Beyşehir ilçesinde milli park, arkeolojik sit alanı, doğal sit alanı, kentsel sit alanı gibi farklı statüde koruma alanları bulunmaktadır. 1957 yılında orman muhafaza alanı ilan edilen Beyşehir'de 1989 yılında Beyşehir Gölü ve çevresi 1. ve 2. Derece doğal sit alanı ilan edilmiş, daha sonra göl çevresindeki kırsal yerleşmeler 3. Derece doğal sit olarak değiştirilmiş̧ir. Kuşluca, Akburun, Gölkaşı, Karadiken, Kurucuova, Çiftlik ve Gölyaka kırsal yerleşmeleri 3.derece doğal sit alanı içinde kalan yerleşmelerdir. Beyşehir ilçesinde göl kenarında bulunan ve eski adıyla İçerişehir olarak bilinen Eşrefoğlu Cami ve Külliyesi'nin bulunduğu bölge 1988 yılında, Doğanbey kırsal yerleşmesinde bulunan geleneksel mimari özellikleri yansitan eski evlerin bulunduğu bölge 2006 yılında kentsel sit alanı ilan edilmiştir.

Beyşehir Gölü 1993 yılında milli park ilan edilmiş olup Beyşehir Gölü ve yakın çevresi ile birlikte 88,750 ha'lık bir alanı kaplamaktadır. Türkiye'deki milli parklar içinde kapladığ alan bakımından ikinci büyük milli park olan Beyşehir Gölü Milli Parkının 68,893 ha'lık kısmı Konya il sınırları içinde yer almaktadır. Beyşehir Gölü’nün Isparta il sınırları içinde kalan kısmı ise Kızıldağ Milli Parkı olarak adlandırılmaktadır (Göktuğ ve Arpa, 2016). Coğrafi konumu açısından bir geçit özelliği gösteren Beyşehir ilçesi ve kırsalının; konut, turizm ve sanayi gelişimini kısıtlaması ve tarım arazilerinde halkın tarımsal faaliyetlerini, mera alanlarında ise hayvancılık faaliyetlerini kısıtlaması nedeniyle 28 Kasım 2018 tarihli Resmî Gazetede Kızıldağ ve Beyşehir Gölü Milli Parkı Sınırları değiştirilmiştir.
Milli Park alanlarına ilişkin yürürlükteki yasal mevzuat, Beyşehir Gölü Milli Parkı'nda çeşitli çatışmalara ve ekonomik çeşitliliğin ortaya çıkmasında engelleyici bir unsur olarak görülmektedir. Milli parkların yönetim planlarının amaçlarına ulaşılabilmesi için kırsal kalkınmayı desteklemek, yerel ekonomi için alternatif kaynaklar oluşturmak, mekânı daha rasyonel kullanmak, yerel halkta koruma bilincini oluşturabilmek adına koruma alanlarında bütüncül planlama ve stratejilerinin geliştirilmesi ve aktörlerin karar alma sürecinde birlikte hareket etmeleri gerekmektedir (Kervankıran ve Eryılmaz, 2015). Ancak 1993 yılında Milli Park ilan edilen Beyşehir Gölü Milli Park1, kanunun getirmiş olduğu kısıtlamalar ile kırsal yerleşmelerde ekonomik ve sosyal gelişme dinamiklerinin ortaya çıkmasına engel olmuştur. Bu çelişkili durum, Beyşehir Gölü Milli Park sınııının 2018 yılında revize edilmesiyle aşılmaya çalışılmış olsa da, özellikle doğal kaynakların korunmasına yönelik tehditlerin önünü açmış olduğu söylenebilir.

\subsection{Beyşehir Kırsalının Ekolojik, Ekonomik ve Kültürel} Dirençlilik Düzeyi

Dirençlilik kavramının temelini oluşturan ekolojik, ekonomik ve kültürel dirençlilik tartışmaları, Beyşehir kırsalı özelinde gerçekleştirilen alan çalışması ve ikincil kaynaklardan elde edilen bilgiler çerçevesinde değerlendirilmiştir. $\mathrm{Bu}$ değerlendirmeler neticesinde, Beyşehir kırsalının olağanüstü gelişmeler karşısında farklı davranış biçimleri gösterme becerisine sahip olduğu tespit edildiği gibi, kırsal yerleşmelerin sahip oldukları sosyo-ekonomik ve mekânsal karakteristikleri dirençlilik düzeyinin farklılaşmasında belirleyici olduğu söylenebilir.

Beyşehir Gölü Kenarl ve Eski Milli Park Sinırında Yer Alan Kırsal Yerleşmelerin Dirençlilik Analizi

Beyşehir Gölü kenarında kurulmuş kırsal yerleşmelerde yapılan alan çalışmasında, ekonomik kaygıların ortaya çıktığ dönemlerde ekolojik açıdan hassas bölgelerin tahribatına yönelik girişimlerin yoğunlaştığ 1 tespit edilmiştir. Özellikle Beyşehir Gölü Milli Parkı gibi önemli koruma statülü bir alanda kurulmuş kırsal yerleşmelerde, kırsal alanda yaşayanlar milli park statüsünün getirdiği kısıtlamaları aşmak adına ekolojik alanların tahribatına yol açmışlardır. Örneğin Beyşehir Gölü çevresindeki kırsal yerleşmelerde yaşayanların alternatif ekonomik faaliyet olarak yürüttükleri balıkçılık faaliyetleri göldeki balık popülasyonunun azalmasında ve bazı balık türlerin yok olmasında etkili olmuştur. 
"Köyümüzde balıkçıllk faaliyeti durma noktasına geldi. Bunun nedeni gölde balık kalmad, kabahatlisi de biziz. Çünkü bilinçsizce yapılan balıkçılık faaliyetleri ve tarımsal atıkların göle dökülmesi, şu anda önemli ekonomik gelir kaynağımı olan gölün kaybına yol açtı (Gölkaşı kırsal yerleşmesinde yapılan görüşmeler)."

Yanı sıra, iklim değişikliği, bilinçsiz avlanma ve su kirliliği gibi faktörler Beyşehir Gölü'nü olumsuz biçimde etkilemiştir. Sulama projeleri ve tarım arazileri için bilinçsiz su kullanımı, iklim değişikliği nedeniyle buharlaşmanın artması gibi olumsuzluklar; Beyşehir Gölü'nde su seviyesinin düşmesine neden olmakla birlikte, su altındaki ekosistemi önemli düzeyde etkilemiştir. Beyşehir Gölü'nde suyun sığlaşması sonucu gölün tabanı yoğun güneş 1şı̆̆1 almakta ve sucul bitkilerin üreyerek kapladığ alanlar artmaktadır (Fethi vd., 2015). Su seviyesinin düşmesinin engellenmesi için Gembos tüneliyle Derebucak bölgesinden göle su taşınması ekolojik açıdan bir dirençlilik oluşmasına fayda sağlamış olsa da gölde balıkçılık faaliyetlerini desteklemek adına geliştirilen endüstriyel balık türü olan tatlı su levreğinin zamanla et yiyen bir balık türü olarak çoğalması diğer balık türlerinin yok olmasina neden olmuştur (Aköz, 2019). Ekolojik dengede yaşanan bozulma, özellikle göl ve doğal kaynaklara dayalı ekonomik faaliyetlerin baskın olduğu kırsal yerleşmelerin direnç düzeyini düşürmüştür. Beyşehir Gölü kenarında yer alan kırsal yerleşmelerin neden olduğu doğal kaynak tahribatı, kırsal alanların tatmin edici bir yaşam standardı yakalama şansını ortadan kaldırmıştır.

"Mahallemiz doğal güzellikleri ve ulaşım imkânları açısından oldukça güzel bir yerde bulunmaktadır. Mahallemizin yakınında bulunan Beyşehir Gölü kenarındaki kamp alanlarl, turistlerin ilgisini çekiyor, bu da bize ekonomik açıdan avantajlar sağlayabiliyor. Ancak köyümüz Milli Park içerisinde olması nedeniyle tarımsal üretim aşamasinda ve hayvanlarımızın yayılmasında kurumlarla sıkıntı yaşıyoruz. Mahallemizde gerçekleştireceğimiz en küçük uygulamalarda ayn sıkıntıyla karşılaşıyoruz. Milli parktan dolayı bir çivi bile çakamıyoruz. Bu bazen mahallemizin terkedilmesine neden olabiliyor (Yeşildăg kırsal yerleşmesinde yapılan görüşmeler)."

"Bölgenin Milli Park olarak ilan edilmesinin nedeni bölgedeki ekolojik çeşitliliğin korunmasıdır. Tabii ki, tarım alanlarının genişletilmesi yoluyla ekolojik yapının tahribatı da önlenmektedir. Ancak koruma statüsü bölge insanına zorluk çıkarmayacak esneklikte olması gerektiüi bilincindeyiz (Beyşehir Milli Parklar Müdürlügü).,"
Bir bölgenin korunan alan statüsüne alınmas1, biyolojik çeşitliliğin korunmasında önemli stratejilerden biri olarak görülür (Allendorf vd., 2007). Dünyada olduğu gibi Türkiye'de de özellikle kırsal kesimdeki korunan alanların çoğu insan yerleşimlerine yakın bölgelerde yer almakta ve bu alanlardan sağlanan faydalar alanın içerisindeki veya çevresindeki halk için geçim kaynağı olmaktadır (Kuvan, 2005; Demirayak, 2006). Ancak korunan bölgelere ilişkin yasal statü kazandırılması neticesinde, kaynak kullanımlarında özellikle yerel halk ile alan yönetimi arasında sosyal çatışmalar söz konusu olabilmektedir (Çolakkadıŏlu, 2012; Bragagnolo vd., 2016). Çünkü doğal kaynaklardan yararlanan bölge insanları hem bu kaynaklardan uzaklaştırılmakta hem de çeşitli turizm aktiviteleri ile bölge dışından gelen turistlerin çeşitli olumsuzluklarına maruz kalmaktadır (Yıldız ve Atmiş, 2019). Bu çatışma süreci 1993 yılında ilan edilen Beyşehir Gölü Milli Parkı içerisinde bulunan kırsal yerleşmeler ile Milli Parklar Genel Müdürlüğü arasında son derece yoğun biçimde yaşanmıştır. Bu çatışmanın ortadan kaldırılması için 2018 yılında Beyşehir Gölü Milli Parkı sınırları değiştirilerek, kırsal yerleşmeler ve tarım alanları milli park statüsünden çıkarılmıştır. Bu çerçevede, Beyşehir kırsalının özellikle ekolojik açıdan direncini artıran koruma statülerinin, son yıllarda esnetildiği görülmüştür. Koruma sınırlarının değişikliğine ilişkin alınan kararların katılımcı bir anlayıştan uzak olması gelecek dönemlerde benzer problemlerin doğmasına yol açabilecektir. Temel hedefi bölgedeki ekolojik ve biyolojik çeşitliliğin korunması olan koruma statülü alanların sınırlarına ilişkin bu baskılar, ekolojik ve biyolojik çeşitliliğin korunması sürecini olumsuz etkileyebilecektir. Dolayısıyla Beyşehir Gölü kenarında yer alan kırsal yerleşmelerin ekolojik direnci zayıflamış olacaktır.

Bölgede milli park ve doğal güzellikler ile tarihi değerlerin turizm sektörüne kazandırılmasına yönelik çabaların, kırsal alandaki ekonomik faaliyetlerin turizm odaklı çeşitlenmesinde önemli rol oynadığı tespit edilmiştir. Kırsal turizmin ekonomik krizler karşısında en dirençli faaliyetlerden biri olması, Beyşehir Gölü kenarındaki kırsal yerleşmelerin ekonomik dirençliliğini arttırmaktadır. Beyşehir Gölü Milli Parkı içerisinde bulunan kamp-karavan, tabiat yürüyüşü, foto safari, bisiklet turu, su kayağı ve tekne turu gibi aktiviteler kırsal yerleşmeler için önemli ekonomik faaliyetlerdir. Bu çerçevede, Beyşehir gölü kenarı ve eski milli park sınırında bulunan kırsal yerleşmelerdeki genç nüfusun önemli bir bölümü rehberlik, pansiyonculuk ve perakende ticaret gibi faaliyetlere yönelmiştir.

Milli park dışındaki orman köyleri özellikle ekonomik gelirlerini arttırmak adına bölgenin ekolojik ve biyolojik 
çeşitliliğinden önemli ölçüde beslenmektedir. Örneğin Beyşehir ilçe merkezinin batı ve güneybatısında bulunan Dedegöl Dağları'na yakın kırsal yerleşmeler, sadece nisan ayının ortasından mayıs ayı sonuna kadar ormanlık alan içinde yetişen ve çeşitli hastalıklara karşı şifa özelliği bulunan kuzugöbeği adı verilen mantar türünü toplayıp satarak ek gelir elde edebilmektedir.

"Nisan ayı sonunda kuzugöbeği mantarını toplamak için çevre yerleşmelerden gelenler çok olur. Yurtdışına mantar toplanıp satılır (Kurucuova kirsal yerleşmesinde yapılan görüşme)."

Ovalık Alanda Yer Alan Kırsal Yerleşmelerin Dirençlilik Analizi

Ekolojik ve morfolojik özellikleri sayesinde tarım sektörünün baskın olduğu ovalık alanda yer alan kırsal yerleşmeler, Beyşehir ilçesinin tarımsal üretim çeşitliliği açısından en önemli bölgeleridir. Bölgede tahıl üretiminden bitkisel üretime, sebze üretiminden meyve üretimine, küçükbaş hayvancılıktan büyükbaş hayvancılığa birçok tarımsal faaliyet birlikte yürütülmektedir. Bu üretim çeşitliliği, ovalık alanda yer alan kırsal yerleşmeleri tarımsal gelir açısından avantajı bir konuma getirirken, tek bir ekonomik faaliyete olana bağımlılık şoklar karşısında kırılgan bir yapıya sahip olmasına yol açmaktadır. Dolayısıyla tarımsal üretimin geleneksel yöntemler kullanılarak yapılması ve tarımda makineleşme oranının düşüklüğü yerleşmelerin dirençliliğinin azalmasına neden olmaktadır. Özellikle Hüyük ve Seydişehir gibi komşu ilçe kırsallarında organik tarım faaliyetlerine geçilmesine karşın, Beyşehir kırsalının bu anlamda gerekli adımları atmadığı belirlenmiştir.

"Tarım ve hayvancllı bizim bölgemizde yeterince gelişmedi. Bunun en önemli sebebi özellikle çiftçilikle uğraşan bizlerin geleneksel üretim biçimlerini değiştirmekte cesaretsiz olmamı ve eğitim düzeyi yüksek gençlerimizin köyümüzü terk etmesidir. Örneğin yakınımızda bulunan Seydişehir ve Hüyük ilçelerine bağlı köylerde organik tarım ve iyi tarım uygulamaları başlamış olmasına karşın, bizim bölgemizde herhangi bir gelişme söz konusu değildir (Küçükavşar, Emen ve Eylikler yerleşmelerinde yapılan görüşme)."

Tarımsal üretimin artmasına bağlı olarak pazar entegrasyonunun gelir artırıcı etkisi sürdürülebilir kalkınmaya kap1 aralarken, güç ilişkileri ve çok düzeyli kurumsal etkileşimlerin yetersizliğinin ortaya çıkardığı zayıf gıda sistemleri kırsalın direncini azaltmaktadır (Sietz ve Feola, 2016).
Son yıllarda, tarımsal üretimdeki çeşitlilik potansiyeli tam anlamıyla kullanılamamakla beraber, kurumsal çabalar ve üretici örgütleri ile sağlanan güçlü ağlar sayesinde tarımsal çeşitliliğe yönelik yenilikçi politikaların uygulanmaya başlandığını söylemek mümkündür. Özellikle tahılgiller, buğday, arpa, pancar ve patates üretiminin yoğun olduğu görülen ilçe merkezinin kuzeydoğusunda bulunan kırsal yerleşmelerde, sosyal sermaye potansiyeli kullanılarak bölgedeki üreticilerin kumpir ve cips patatesi üretimine geçmesi sağlanmıştır. Tarım sektöründe yeni ürünler elde etmeye çalışan Sadıkhacı kırsal yerleşmesinde karpuz, Esence kırsal yerleşmesinde kabak çekirdeği ve haşhaş, Bayavşar kırsal yerleşmesinde susam üretimine başlanmıştır.

"Mercimek yerel pazarda bilinen bir ürünümüzdür. Bu sene farkl olarak karpuz yetiştirmeyi denedik ve üretim verimli oldu. Yerel pazarda ciddi bir talep oluştu. Üretime devam etmeyi düşünüyoruz (Sadıkhacı yerleşmesinde yapılan görüşme)."

"Buğday ve arpa haricinde haşhaş üretimine de iznimiz var. Yerel halk son iki senedir kabak üretimini de artırd. Toptancllar kabak çekirdeklerini almaya geliyorlar (Esence yerleşmesinde yapılan görüşme)."

Bir ekonominin dirençliliği yenilikçilik ve rekabetçilik kapasitesiyle doğrudan ilişkilidir. Beyşehir kırsalında hâkim sektör olan tarımsal üretimin yenilikçilik kapasitesi, bölgenin ekonomik dirençliliği açısından önemli bir unsurdur. Tarımsal üretimde yenilikçiliği genel olarak üç kriterde ele almak mümkündür: teknolojik değişim, kurumsal reformlar ve üretici örgütlenmesi. Teknolojik değişim modern teknolojinin tarıma dâhil edilmesi yoluyla girdilerin azaltılması ve verimliliğin arttırılmasını içermektedir. Kurumsal reformlar hane halkı ile tarım arazisi arasındaki ilişkiler ile gelir dağılımının düzenlenmesi, toplulaştırma, sulama ve toprak ıslahı faaliyetleri içeren eylemler olarak görülmektedir. Üretici örgütlenmesi ise, birlikte karar alma sonucu sorumluluk anlayışının oluşturulması, kaynakların etkin kullanımı ve kolektif hareketin geliştirilmesi olarak kabul edilmektedir (İnan, 2004'ten aktaran Kepoğlu ve Gülçubuk, 2014). Ekonomisi tarıma dayalı olan ovalık kırsal yerleşmelerin dirençliliğinde çeşitlenme eğiliminde olan tarımsal faaliyetler olumlu bir yönde etki ederken, yenilikçilik ve rekabetçilik düzeyinin düşük olması dezavantaj olarak değerlendirilmektedir. Bölgede tarım haricinde ekonomik dirençliliği etkileyecek; Bayavşar kırsal yerleşmesinde imalat faaliyetleri (cips, parke ve mermer fabrikası) ile Sadıkhacı kırsal yerleşmesi sınırları içinde kırsal turizm potansiyelini destekleyecek Eflatunpınar Anıtı bulunmaktadır. 
Bununla birlikte belirtilmesi gereken bir diğer husus ise, kırsal alanlarda dirençliliği arttıran temel unsur tarımsal üretim ve verimliliği geliştirmek değil, öğrenme ve uyarlanabilir bir üretim yapısını hakim kılmaktır (Spector vd., 2019). CradockHenry (2017) iklim değişkenliği, kentleşme ve piyasa riskleri ile ilişkili olarak kırsal toplulukların tehlikelere karşı dirençlilik oluşturmak için hem stratejik hem de üretim organizasyonlarında çeşitli stratejileri belirleyecek öğrenme yollarının keşfedilmesi gerektiğini belirtir. Bu çerçevede, Beyşehir kırsalının yeni bir üretim organizasyonuna uyum sağlama kapasitesini arttıran mekanizmaların henüz istenilen düzeyde olmadığı görülmektedir. Üretim olanakları açısından önemli potansiyele sahip ovalık alanda yer alan kırsal yerleşmelerin yeni üretim yöntemlerine ve işgücü kaynaklarına yönelik desteklenmesi yoluyla daha dirençli alanlara dönüşme olanağ 1 söz konusudur. $\mathrm{Bu}$ yeni bir organizasyon biçimini zorunlu kılmaktadır. Diğer bir yandan, yerleşmelerde var olan yaşlı nüfusun artması ve genç nüfusun göç etmesi sorunu bulunmaktadır. Bu sorun kırsal topluluklarda bilgi ve becerilerin genç nesle aktarılamamasına, sosyal hafızanın bozularak kırsal dirençliliğin azalmasına neden olmaktadır. Nitekim ovalık alanda yer alan kırsal yerleşmelerde de geleneksel el sanatı olarak önemli bir gelir kaynağ 1 olan halı ve kilim dokumacılığının bitmesine neden olmuştur. Bu durum kültürel dirençliliğin azalmasına yol açmaktadır.

"Kenevir üretiminin olduğu dönemlerde, yaşlılar kenevir sapindan ip üretirdi. Üretilen ipi hem fabrikalara satar hem de kendi becerilerimizi kullanarak kilim dokurduk. Bu ekonomik açıdan bir gelir kaynă̆g olarak değerlendirilirken, kültürel alışkanlıklarımızı ve davranışlarımızı geliştirme olanağ yakalayabiliyorduk. Ancak günümüzde gençlerin çoğunluğu köyden kente göç ediyorlar. Bu bilgi aktarımı ve üretimin yapılacağl insan pek kalmadl ve yavaş yavaş bu kültür unutulmaya yüz tuttu (Emen'de yapılan görüşme)."

\section{Ĕ̆imli/Dağllk Alanda Yer Alan Kırsal Yerleşmelerin} Dirençlilik Analizi

Eğimli/dağlık alanda yer alan kırsal yerleşmeler; morfolojik ve toprak yapısının dezavantajlarından dolayı daha çok kuru tarım, hayvancılık ve imalat faaliyetlerinden kazanç sağlamaya çalışmaktadır. Hayvancılık faaliyetlerinin yoğun olduğu eğimli/ dağlık alanda yer alan kırsal yerleşmelerin ekonomik dirençlilik düzeyinin oldukça düşük olduğu söylenebilir. Ancak bu olumsuz koşullardan kurtulmak adına, çeşitli girişimcilik faaliyetlerinin son yıllarda ortaya çıktığı görülmektedir. Özellikle Doğanbey kırsal yerleşmesinde et ve sucuk üretimine dayalı "Doğanbey Sucukları" markası altında ilçe merkezi, Konya ve İzmir illerine satışlar yaparak hayvancılık sektörünün desteklenmesi sağlanmaktadır. Yanı sıra Doğanbey kırsal yerleşmesinde Beysu fabrikası ve un fabrikası tarım dışı ekonomik faaliyetlerdendir.

"Et ve sucuk imalathanelerimiz var ama besicilik yeterli değil. Süt toptancllı̆̆ ve besiciliğin desteklenmesini isterdim. Buraya özgü olan marka daha iyi yerlere gelebilir. Başka insanlara da gelir kapıst olabilir (Doğanbey Sucuklart Girişimcisiyle yapılan görüşme)."

Eğimli/Dağlık alanda yer alan kırsal yerleşmelerin ekonomik dirençliliğini arttıran en önemli sektör ise, imalat sanayi faaliyetleridir. Kırsal yerleşmelerin ekonomik faaliyetleri ile ilişkilendirmenin oldukça zor olduğu, imalat sanayi faaliyetleri açısından Beyşehir kırsalının Huğlu ve Üzümlü yerleşmeleri önemli potansiyel göstermektedir. $\mathrm{Bu}$ potansiyel özellikle Beyşehir'in batısında bulunan kırsal yerleşmeler açısından da önemli istihdam alanı oluşturduğundan, bölgenin ekonomik dirençliliğini önemli düzeyde arttırmaktadır. Örneğin Huğlu ve Üzümlü’de bulunan firmalar aylık 30.000 adet tüfek üretimi ve 7.000 kişilik istihdam ile kırsal yerleşmeler için önemli istihdam kaynağı niteliğindedir. Beyşehir Silah Sanayicileri ve İş Adamları Derneği (BEYSİSAD) tarafından 2010 yılında hazırlanan rapora göre sadece Beyşehir'in Üzümlü ve Huğlu kırsal yerleşmeleri Türkiye'deki av tüfeği üretiminin \%70'ini gerçekleştirmiştir. Amerika, Kanada, Güney Afrika, Mısır, Ürdün, Kazakistan, Özbekistan, Azerbaycan, Rusya, Almanya, Fransa, İngiltere, Danimarka, Norveç gibi ülkeler başta olmak üzere, dünyanın birçok coğrafyasına tüfek ihraç edilmektedir (Yalçın, 2016). Bölgede gerçekleştirilen görüşmelerde, kırsal alanlarda ortaya çıan imalat sanayi faaliyetlerinin ekonomik açıdan önemli dirençlilik oluşturduğu belirlenmiştir.

"Meslek yüksekokulu ve teknik lisenin varlı̆̆ nitelikli iş gücü oluşturmada fayda sağllyor. Mezun olduktan sonra av tüfeği üretim tesislerine başvuran genç nüfus fazla. Nitelikli iş gücü oluşturmada üniversite ve teknik lisenin faydasını görüyoruz (Huğlu Av Tüfekleri Kooperatifi'nde yapılan görüşme)."

Bir bölgeyi dirençli olarak kabul etmek için güçlü bir bölgesel yenilikçi sistemlerinin, öğrenme yeteneğinin, iyi ulaşım ve altyapı varlığının, eğitimli işgücünün, girişimleri destekleyecek finansal bir sistemin ve çeşitlendirilmiş endüstrinin olması gerekmektedir (Sabatino, 2019). Huğlu kırsal yerleşmesinde yapılan görüşmeler sonucunda av tüfekleri üretiminin yerleşme ekonomisini etkilediği gibi fiziki çevre ve halk ilişkilerini de güçlendirdiği, iş imkânlarından dolayı nüfus çekebilen bir yer olduğu bilgisine ulaşılmıştır. Av tüfeği üretimine eleman 
yetiştirmek için 1978'de Huğlu Teknik ve Endüstri Meslek Lisesi ile 1994 yılında Selçuk Üniversitesi Huğlu Meslek Yüksek Okulu (MYO) kurulmuştur. Lise'nin Makine Teknolojisi Bölümü ile MYO'nun Makine ve Metal Teknolojileri Bölümü, Huğlu Silah Sanayisine yetişmiş işgücü kazandırmaktadır (Yalçın, 2016).

"Av tüfeği üretim tesislerinin varlığıyla göç alan bir mahalle. Fabrikalarda çalışanlar, kiralar ilçe merkezine göre daha uygun olduğu için burada yaşamayı tercih ediyor. Genç nüfusun diğer yerleşmelere oranla fazla olduğunu söyleyebiliriz. Mahallemiz gelişmiştir. Ihtiyaçlarımızı giderebiliyoruz. İlçe merkezine evrak işleri, sağllk hizmetleri, banka işleri için gidiyoruz. Kasabaya ait otobüs firmalarıyla veya belediye otobüsüyle ulaşımımı rahat (Huğlu yerleşmesinde yapılan görüşme)."

Özellikle İzmir ve İstanbul'a yoğun bir şekilde göç veren dağlık kırsal yerleşmelerde emekli nüfusun yaz aylarında köylerine gelerek kendi ihtiyaçlarını karşılayacak kadar tarım işlerini sürdürdükleri ve memleketleriyle bağlarını kopartmadıkları gözlemlenmiştir. Sosyal dayanışma ve yardımlaşmanın bulunduğu kırsal yerleşmeler çevresel ve fiziki özellikleriyle ön plana çıkmış, bakımlı ve ekonomik gelir durumunun yüksek olduğu yerlerdir. Akçabelen kırsal yerleşmesinde yapılan görüşme sonucunda özellikle yurt dışında yaşayan gelir düzeyi yüksek nüfusun kırsal yerleşmenin ekonomik ve teknik altyapı sorunlarının giderilmesinde inisiyatif aldıkları tespit edilmiştir.

"Burada yaşayan insanların çoğu yurt dışından emekliliğini hak ederek geri dönmüştür. Ekonomik gelir düzeyimiz iyi olduğu için mahallemizin ihtiyaçlarını kendimiz karşılarız. Cami ve yol bakımını yaparız. Etrafi düzenleriz (Akçabelen yerleşmesinde yapılan görüşme)."

“İzmir'de yaşayan yaklaşık 17.000 Doğanbeyli var. Bağlarımızı hiç koparmadık. Doğanbey Vakfı adı altında her sene Haziran veya Temmuz ayında mahallemizde şölen düzenlenir. Diğer illerde yaşayan halkımız da katılır (Doğanbey yerleşmesinde yapılan görüşme)."

Eğimli/dağlık alanda yer alan kırsal yerleşmelerde sosyal ilişkileri güçlendirmek ve bölge dışında yaşamını sürdüren hemşeriler ile etkileşimler sağlamak adına Huğlu Tüfek Bayramı, Doğanbeyliler Kültür, Bilim, Etkinlikleri ve Festivali, Karahisar Köyü Piknik Şöleni gibi bir dizi etkinlik düzenlenerek, bölgenin sahip olduğu dezavantajların giderilmesi amaçlanmaktadır.
"Tarım arazilerimizin parçalı ve verimsiz olmast, hane halkının yıllık gelirini sağlayacak bir tarımsal üretime olanak tanımamaktadır. Bundan dolayl, köyümüz İzmir ve İstanbul'a çok fazla göç vermektedir. Fakat her sene yaptığımız piknik şölenine herkes katılmaya çalışır, şehir dışındakiler ziyarete gelir (Karahisar yerleşmesinde yapılan görüşmeler)."

\subsection{Beyşehir Kırsalının Dirençlilik Düzeyine İlişsin} Değerlendirme

Beyşehir Gölü kenarında ve eski milli park sınırında yer alan kırsal yerleşmeler tarihi süreç içerisinde birçok şokla karş1 karşıya kalmıştır. Gölde meydana gelen taşkın ve sel felaketleri sonrası artan salgın hastalıklar, iklim değişikliği ve gölden su çekimlerinin neden olduğu su seviyesindeki azalma, gölün flora ve fauna dengesinin bozulması ile kırsal yerleşmelerde yaşanan yangınlar bu şoklardan bazılarıdır. Göl kenarında kurulmuş kırsal yerleşmeler, morfolojik özelliklerinin potansiyelini kullanarak ekonomik getirisi yüksek olan sulu tarıma ağırlık vermiş, fakat balıkçılık faaliyetlerinde istenilen düzeyde ekonomik gelir sağlayamamıştır. $\mathrm{Bu}$ durum dirençliliğin azalmasına neden olmuştur. Flora ve fauna çeşitliliğinin fazla olduğu Beyşehir Gölü Milli Parkı çevresinde yer alan kırsal yerleşmelerde halk ve kurumlar arasında arazi yönetimi konusunda yaşanan çatışmaların azaltılması amacıyla sınırlar daraltılmış olup bölgede ekonomik faaliyetlerin daha rahat yapılması amaçlanmıştır. Bu durum ekonomik çeşitlilik üzerinde etki sağlayarak ekonomik direncin artmasını sağlarken, yeni milli park sınırlarının baskı altında kalmasına neden olarak ekolojik çeşitliliğin tahribatını hızlandırmıştır. Beyşehir Gölü Milli Park1 ve çevresindeki kültür turizmi odakları bölgenin kültürel ve ekonomik direncini arttıran temel unsurlardır (Tablo 4 ve 5).

Beyşehir Gölü'nün doğusunda yoğunlaşan kırsal yerleşmelerde, tarımsal faaliyetlerin çeşitli olması dirençliliklerini artırırken, teknolojiye adapte olamamış geleneksel üretim yapılarını sürdürmektedir. Sadıkhacı, Bayavşar, Akçabelen kırsal yerleşmelerinde yeni tarımsal ürünlerin denenmeye başlanması kırsalın ekonomik geliri açısından önemli bir gelişme olarak kabul edilirken, halkın her hafta kent merkezinde kurulan pazar alanlarına gitmeleri kırdan kente yönelik bir etkileşim sağlarken kentten kıra doğru olan etkileşimi zayıflatmaktadır. Bölgede tarımsal üretim dışında farklı ekonomik faaliyetlerin yetersizliği ve zanaatçılığa dayalı üretim kültürünün unutulmaya başlanması, kuşaklar arası bilgi aktarımı açısından neden olduğundan kültürel ve ekonomik açıdan dirençlilik düzeyini olumsuz etkilemektedir (Tablo 4 ve 5). 
Tablo 4: Beyşehir kırsalının dirençlilik düzeyinin değerlendirilmesi.

Table 4: Evaluation of the resilience level of Beyşehir rural areas.

\begin{tabular}{|c|c|c|c|c|c|}
\hline \multicolumn{2}{|c|}{$\begin{array}{l}\text { Göl Kenarı ve Eski Milli Park Sınırında Yer Alan } \\
\text { Kırsal Yerleşmelerin Dirençliliğini }\end{array}$} & \multicolumn{2}{|c|}{$\begin{array}{l}\text { Ovalık Alanda Yer Alan Kırsal Yerleşmelerin } \\
\text { Dirençliliğini }\end{array}$} & \multicolumn{2}{|c|}{$\begin{array}{l}\text { Engebeli/Dağlık Alanda Yer Alan Kırsal } \\
\text { Yerleşmelerin Dirençliliğini }\end{array}$} \\
\hline Zayıflatan & Güçlendiren & Zayıflatan & Güçlendiren & Zayıflatan & Güçlendiren \\
\hline $\begin{array}{l}\text { İklim değişikliklerine } \\
\text { bağlı olarak Beyşehir } \\
\text { Gölü'nün su seviyesinde- } \\
\text { ki azalma }\end{array}$ & $\begin{array}{l}\text { Morfolojik yapının farklılık } \\
\text { göstermesine bağlı olarak } \\
\text { tarımsal ve biyolojik } \\
\text { çeşitliliğin olması }\end{array}$ & $\begin{array}{l}\text { Teknolojiye adapte ola- } \\
\text { mamış gelenekçi tarımsal } \\
\text { üretim }\end{array}$ & $\begin{array}{l}\text { Bölgenin doğal yapısıyla } \\
\text { uyumlu bir şekilde tarımsal } \\
\text { faaliyetlerin çeşitlenmesi }\end{array}$ & $\begin{array}{l}\text { Hayvancılık faaliyetleri- } \\
\text { nin yem fiyatlarının art- } \\
\text { masından dolayı yeterli } \\
\text { seviyede olmaması }\end{array}$ & $\begin{array}{l}\text { İmalat sektörünün (av } \\
\text { tüfeği üretim tesisleri } \\
\text { vb.) gelişmiş olması }\end{array}$ \\
\hline $\begin{array}{l}\text { Milli Park sınırlarının } \\
\text { daraltılmasıyla yeni } \\
\text { sınırların baskı altında } \\
\text { kalacak olması }\end{array}$ & $\begin{array}{l}\text { Yaşanan doğal afetler } \\
\text { sonrasında (yangın, sel, } \\
\text { hastalık vb.) doğal ya- } \\
\text { şamla uyumlu bir şekilde } \\
\text { yapı malzemesi ve yer } \\
\text { seçimindeki değişiklikler }\end{array}$ & $\begin{array}{l}\text { Hayvancılık faaliyetlerinin } \\
\text { yem fiyatlarının artma- } \\
\text { sından dolayı yeterli } \\
\text { seviyede olmaması }\end{array}$ & $\begin{array}{l}\text { Morfolojik özelliklerinin } \\
\text { ve toprak kabiliyetinin } \\
\text { tarımsal üretimde verimlilik } \\
\text { sağlaması }\end{array}$ & $\begin{array}{l}\text { Turizm potansiyeli bu- } \\
\text { lunan kırsal yerleşme- } \\
\text { lerdeki alt yapı eksikliği }\end{array}$ & $\begin{array}{l}\text { Kırsal yerleşmelerden } \\
\text { göç edenlerin mem- } \\
\text { leketleriyle bağlarını } \\
\text { kopartmaması }\end{array}$ \\
\hline $\begin{array}{l}\text { Beyşehir Gölü'ndeki flora } \\
\text { ve faunanın bozulması }\end{array}$ & $\begin{array}{l}\text { Milli park ve tarihi kül- } \\
\text { türel yapıların varlığıyla } \\
\text { turizm sektörü açısından } \\
\text { potansiyel barındırması }\end{array}$ & $\begin{array}{l}\text { Yaşlı nüfusun artmasıyla } \\
\text { kırsal yerleşmelerde } \\
\text { canlılığın yok olması }\end{array}$ & $\begin{array}{l}\text { Yeni tarımsal üretimlere yer } \\
\text { verilmesi }\end{array}$ & $\begin{array}{l}\text { Morfolojik ve iklimsel } \\
\text { özelliklerinin tarımsal } \\
\text { üretimin istenilen } \\
\text { düzeyde olmaması }\end{array}$ & $\begin{array}{l}\text { Nitelikli iş gücü oluş- } \\
\text { masını sağlayan eğitim } \\
\text { kurumları ile imalat } \\
\text { sektörü arasındaki iş } \\
\text { birliği }\end{array}$ \\
\hline $\begin{array}{l}\text { Beyşehir Gölü'nün } \\
\text { varlığıyla potansiyel } \\
\text { ekonomik sektör olarak } \\
\text { görülen balıkçılığın } \\
\text { azalması }\end{array}$ & $\begin{array}{l}\text { Tarihsel süreç içinde farklı } \\
\text { milletlerden göç alarak } \\
\text { kültürel mirasına ve eko- } \\
\text { nomisine katkı sağlaması }\end{array}$ & $\begin{array}{l}\text { Unutulmaya yüz tutmuş } \\
\text { el sanatlarının ekonomik } \\
\text { destek sağlayamaması }\end{array}$ & & & $\begin{array}{l}\text { Tescillenmiş gıda ürün- } \\
\text { lerinin bulunması }\end{array}$ \\
\hline $\begin{array}{l}\text { Milli park sınırlarına } \\
\text { yakın kırsal yerleşmelerle } \\
\text { kurumlar arasında tarım } \\
\text { ve hayvancılık konusun- } \\
\text { da çatışmaların olması }\end{array}$ & & $\begin{array}{l}\text { Tarımsal üretimde elde } \\
\text { edilen ürünlerin satıldığı } \\
\text { pazar alanlarının bulun- } \\
\text { maması }\end{array}$ & & & $\begin{array}{l}\text { İmalat sektörünün ge- } \\
\text { lişmiş olmasılyla birlikte } \\
\text { göç alan yerleşmeler } \\
\text { olması }\end{array}$ \\
\hline $\begin{array}{l}\text { Yaşlı nüfusun artmasıyla } \\
\text { kırsal yerleşmelerde } \\
\text { canlılığın yok olması }\end{array}$ & & & & & $\begin{array}{l}\text { Örgütlenme faaliyet- } \\
\text { lerinin (dernek, oda } \\
\text { vb.) aktif olması ile göç } \\
\text { edenlerin }\end{array}$ \\
\hline
\end{tabular}

Beyşehir Gölü'nün batısı ve güneyinde engebeli/dağlık alanda yer alan kırsal yerleşmeler, morfolojik özelliklerinin dezavantajlarından dolayı çoğunlukla kuru tarım, imalat ve hayvancilık faaliyetlerinden gelir elde etmektedir. Ancak bölgede, imalat sektörünün gelişmiş olması ekonomik dirençlilik açısından oldukça önemlidir. İmalat sektörünün gelişmişliği, nitelikli iş gücü ve genç nüfusun bu bölgeye göç etmesini sağlayarak kültürel dirençliliği olumlu yönde etkilemektedir. Örgütlenme faaliyetlerinin (dernek, kooperatif vb.) aktif olması, kültürel dirençliliği artırırken ekonomik faaliyetlerin hem yerel hem ulusal pazarda etkili olmasını sağlamaktadır (Tablo 4 ve 5).

Beyşehir kırsalı, literatür araştırması ve arazi çalışmasında elde edilen veriler ışığında dirençliliği etkileyen faktörlere göre puanlandırılmıştır. Ekolojik dirençlilik değişkenlerine göre ovalık alanda yer alan kırsal yerleşmeler; arazi yapısının ekonomik faaliyetler açısından uygun olması, koruma statüsü açısından engeller ya da kısıtlamaların olmaması, arazi kullanım biçimleri ve çeşitliliğinin avantajlarının fazla olması nedeniyle diğer iki gruba göre daha dirençli yerleşmelerdir. Morfolojik ve iklimsel özellikler açısından dezavantajlı olması, tarım arazilerinin parçalı ve verimsiz olması, yoğun orman alanlarının varlığı nedeniyle engebeli/dağlık alanda yer alan kırsal yerleşmeler direnç oranının en düşük olduğu yerleşmelerdir. Kültürel dirençlilik değişkenlerine göre; yerleşmede kültürel faaliyetlerin devamını sağlayacak örgütlenme varlığı, halk katılımının sağlanması, nüfus tutabilme kabiliyeti ve toplumsal gelenek ve göreneklerin yoğunluğu eğimli/dağlık alanda yer alan kırsal yerleşmelerin dirençlilik düzeyinin en yüksek olmasını sağlamaktadır. İmalat sektörünün gelişmiş olmasıyla nüfus tutabilme gücü, kooperatif ve derneklerle kültürel etkinliklerin ve yardımlaşmanın sağlanması, av tüfeği üretiminin geçmişten günümüze ulaşan yol bağımlı bir faaliyet olması eğimli/dağlık alanda yer alan kırsal yerleşmeleri kültürel dirençlilik düzeyini yükseltmektedir (Tablo 4 ve 5).

Ekonomik dirençlilik değişkenlerine göre, yerel veya ulusal pazara açılmış üretim çeşitliliği, ekonomik faaliyetlerdeki uzmanlaşma düzeyi, bölge dışındaki hemşerilerin ekonomik gelişme adına sağladığı katkıların düzeyi, yerel ve merkezi yönetim kapasitelerinin yatırım düzeyi açısından en dirençli kırsal yerleşmeler eğimli/dağlık alanda yer almaktadır. Eğimli/ 
Tablo 5: Beyşehir kırsalının dirençlilik değişkenlerinin karşılaştırılması.

Table 5: Comparison of resilience variables of Beyşehir rural areas.

\begin{tabular}{|c|c|c|c|c|}
\hline Dirençlilik & Değişkenler & $\begin{array}{l}\text { Beyşehir Gölü } \\
\text { Kenarı ve Eski Milli } \\
\text { Park Sınırında } \\
\text { Yer Alan Kırsal } \\
\text { Yerleşmeler }\end{array}$ & $\begin{array}{l}\text { Ovalık Alanda } \\
\text { Yer Alan Kırsal } \\
\text { Yerleşmeler }\end{array}$ & $\begin{array}{l}\text { Eğimli/Dağlık } \\
\text { Alanda Yer Alan } \\
\text { Kırsal Yerleşmeler }\end{array}$ \\
\hline \multirow[t]{2}{*}{ Ekolojik Dirençlilik } & Arazi yapısının ekonomik faaliyetler açısından uygunluk düzeyi, & 0 & +1 & -1 \\
\hline & Ekonomik faaliyetler açısından iklim çeşitliliği ve olanağı, & +1 & 0 & -1 \\
\hline Uygun: 1 & Koruma statüleri açısından ortaya çıkan engeller ya da kısıtlar, & -1 & +1 & 0 \\
\hline $\begin{array}{l}\text { Orta: } 0 \\
\text { Uygun: }-1\end{array}$ & Arazi kullanım biçimleri ve çeşitliliğinin avantajları, & 0 & +1 & -1 \\
\hline \multirow[t]{2}{*}{ Ekonomik Dirençlilik } & Kırsal yerleşmenin Beyşehir ilçe merkezine erişilebilirlik düzeyi, & 0 & +1 & -1 \\
\hline & $\begin{array}{l}\text { Yerleşmenin geçmişten günümüze gelen üretim ve yaşam alışkan- } \\
\text { lıklarııın ekonomik yapısının gelişmesindeki rolü, }\end{array}$ & +1 & -1 & 0 \\
\hline Orta: 0 & Yerel veya ulusal pazara açılmış üretim çeşitliliği, & -1 & 0 & +1 \\
\hline \multirow[t]{5}{*}{ Düşük: -1 } & Yerleşmede desteklenmesi gereken ekonomik faaliyet çeşitliliği, & +1 & -1 & 0 \\
\hline & Ekonomik faaliyetlerdeki uzmanlaşma düzeyi, & -1 & 0 & +1 \\
\hline & $\begin{array}{l}\text { Yerleşmede ekonomik açıdan desteklenmesi önemli ekonomik } \\
\text { faaliyetlerin türü ve rolü }\end{array}$ & +1 & -1 & 0 \\
\hline & $\begin{array}{l}\text { Bölge dışındaki hemşerilerin ekonomik gelişme adına sağladığı } \\
\text { katkıların düzeyi, }\end{array}$ & -1 & 0 & +1 \\
\hline & Yerel ve merkezi yönetimlerin yatırım kapasitesi, & 0 & -1 & +1 \\
\hline \multirow[t]{2}{*}{ Kültürel Dirençlilik } & Çevredeki kırsal yerleşmelerle kültürel ilişkilerin düzeyi, & +1 & 0 & -1 \\
\hline & $\begin{array}{l}\text { Yerleşmede kültürel faaliyetlerin devamını sağlayacak örgütlenme } \\
\text { düzeyi }\end{array}$ & 0 & -1 & +1 \\
\hline \multirow[t]{8}{*}{$\begin{array}{l}\text { Orta: } 0 \\
\text { Düşük: }-1\end{array}$} & $\begin{array}{l}\text { Yerleşmeniz ile ilgili alınması gereken kararlarda halk katılımı } \\
\text { düzeyi, }\end{array}$ & -1 & 0 & +1 \\
\hline & Yerleşmeye bağımlılık düzeyiniz, & -1 & 0 & +1 \\
\hline & Bölge dışından gelenlerin yerleşmeye olan ilgi düzeyi, & +1 & 0 & -1 \\
\hline & $\begin{array}{l}\text { Geçmişten günümüze devam ettirdiğiniz toplumsal gelenek-göre- } \\
\text { neklerin yoğunluğu, }\end{array}$ & -1 & 0 & +1 \\
\hline & $\begin{array}{l}\text { Unutulmaya yüz tutmuş ve desteklenmesi gereken el sanatlarının } \\
\text { çeşitliliği, }\end{array}$ & 0 & +1 & -1 \\
\hline & $\begin{array}{l}\text { Kırsal turizmi ön plana çıkarabilecek mimari, yapı ve sosyal çeşitlilik } \\
\text { düzeyi, }\end{array}$ & +1 & 0 & -1 \\
\hline & Geleneksel üretim teknikleri ve kabiliyetin düzeyi, & 0 & -1 & +1 \\
\hline & SONUÇ & 0 & -1 & +1 \\
\hline
\end{tabular}

dağlık alanda yer alan kırsal yerleşmelerden; Huğlu'da av tüfeği imalatının olması, Doğanbey'de sucuk üretimi ve Beysu tesislerinin varlığı, Akçabelen'de coğrafi işarete sahip fasulye üretiminin olması, bu bölgeyi diğer bölgelere göre daha dirençli yapmaktadır. Yeni tarımsal ürünlerin (karpuz, kabak çekirdeği, susam vb.) olması ve ilçe merkezine yakın konumda kurulmuş olmaları, ovalık alanda yer alan kırsal yerleşmelerde bir potansiyel oluştururken yerleşmede desteklenmesi gereken ekonomik faaliyetlerin düşük olması, bu bölgenin direnç düzeyinin en düşük olmasına neden olmaktadır. Halka iş imkânı sağlayacak fabrikaların varlığı Huğlu kırsal yerleşmesini göç vermekten ziyade göç alan bir yerleşme olmasını sağlamıştır. $\mathrm{Bu}$ durum ekonomik faaliyetlerin varlığının nüfus tutma özelliği sağladığı sonucunu ortaya koymakta, dirençliliği desteklemektedir. Beşerî sermayenin sosyal sermayeyi desteklediği kırsallarda dirençliliğin fazla olduğu görülmüştür. Dolayısıyla, kırsalda var olan güçlü topluluk bağları mevcut ilişkiler, işbirlikçi yapılar ve sosyal sermayeyi etkili bir şekilde kullanarak çeşitli şoklar karşısında dayanıklı bir yapı oluşturabilmektedir. Bu nedenle kırsal için iyileşme süreçlerinin nasıl hızlandırılacağına dair stratejiler ve gerekli düzenlemelere yönelik önlemler sosyal sermaye ve günlük rutinler gibi dinamiklerle ortaya çıkabilmektedir (Spector vd., 2019; Brown vd., 2015).

Ekolojik, ekonomik ve kültürel dirençlilik değişkenlerine göre en yüksek dirençlilik düzeyine sahip kırsal yerleşmeler; morfolojik ve iklimsel özelliklerinin dezavantajlarını imalat faaliyetlerine ağırlık vererek absorbe etmeye çalışan, toplumsal birlik ve beraberliğin sağlandığı eğimli/dağlık alanda yer alan yerleşmelerdir.

\section{SONUÇ}

Kırsal gerileme kavramlarına bir tepki olarak ortaya çıkan kırsal dirençlilik kavramı ekonomik, ekolojik ve kültürel 
dirençlilik, kırsal toplumları pasif ve dış güçlerin etkisi altına bırakmak yerine aktif ve dinamik sosyo-ekonomik süreçler ve düzenlemelerden oluştuğunu savunmaktadır. Kırsal alanların ekolojik dirençlilik kavramı altında incelenen coğrafi konum ve özellikleri, iklimsel özellikler, toprak ve çevre kalitesi gibi faktörler ekonomik ve kültürel özelliklerini de etkilemektedir. Beyşehir kırsalında yapılan araştırmalarda, ekolojik özelliklerin mekânsal gelişmeyi etkilerken o bölgede yaşayan insanların ekonomik faaliyetlerinin de şekillenmesini sağladığı tespit edilmiştir. Tarım arazilerinin verimsiz ve parçalı olduğu bölgelerde farklı ekonomik faaliyetleri ön plana çıkaran yol bağımlı süreçleri tetikleyen unsurların varlığı dirençlilik düzeyinin artmasında etkili olmuştur. Ekonomik coğrafya tartışmalarından dezavantajlı bölgeler olarak kabul edilen eğimli/dağlık alanlar, Beyşehir kırsalının açığa çıkardığı örtük bilgi ve üretim kültürü sayesinde bölge ekonomisini değiştirmiş, ulusal ve uluslararası pazarda önemli bir ekonomik mekânın doğmasına yol açmıştır. Bu tespit her bir mekân parçasının sahip olduğu biriciklik özelliklerinin kullanılması yoluyla ekonomik gelişme yörüngelerinin belirlenmesi politikası için belirleyici olmuştur. Benzer unsurlar ile Doğanbey kırsal yerleşmesi ise hayvancılık faaliyetlerine yönelmiş, sucuk imalathaneleriyle birlikte bu konuda uzmanlaşmış bir ekonomik mekân haline gelebilme becerisi göstermiştir.

Kırsal yerleşmelerin dirençliliğinde; yol bağımlılığı, sosyal ve beşeri sermaye, çeşitlilik, yönetişim, kümelenme, yenilikçilik ve rekabet, turizm potansiyeli, morfolojik yapı, iklimsel özellikler ve toprak yapısı gibi değişkenler birbirini destekler niteliktedir. Ekonomik, kültürel ve ekolojik açıdan dirençli kırsal yerleşmeler, yaşanan bir şok karşısında eski durumunu geri kazanamasa bile öğrenme süreci boyunca yenilikçi değişim ve gelişimler ortaya çıkararak bölge ekonomilerine katk1 sağlayabilmektedir.

Türkiye'de sadece ekonomik veya ekolojik şoklarla karş1 kaşıya olmayan kırsal alanlar; farklı yasal statülerin sosyoekonomik etkisi, hızlı nüfus kaybı ve yaşlı nüfusun artması, yetersiz altyapı gibi durumlarla da karşı karşıyadır. KonyaKaraman bölgesinin önemli alt merkezlerinden biri olan Beyşehir ilçesi kırsalı; Beyşehir Gölü'nde yaşanan ekolojik olumsuzluklar, göç ve farklı yasal statülerin etkileri gibi kırılma noktaları karşısında, coğrafi özellikleri, ekonomik faaliyetlerindeki çeşitlilik, tarihi ve kültürel yapısı ve gelişmiş hizmetler sektörü gibi potansiyellerinden yararlanarak sosyal ve kültürel açıdan önemli direnç mekanizmaları geliştirmektedir. Özellikle yerel düzeyde dayanıklılık oluşturma girişimleri katılımcı ve çözüm odaklı politikaların gerekliliğini ortaya koymaktadır. $\mathrm{Bu}$ çerçevede, kırsal alanlar için ısmarlama esnek çözümler, kritik yaşam hatlarının, altyapının, topluluk bağlarının ve yer bağlantısının mevcudiyetindeki farklılıkların hesaba katılması gerekmektedir. Özellikle tarım ve turizm odaklı ekonomik faaliyetlerle bölgenin sosyal, ekonomik ve kültürel omurgasını oluşturan kırsal alanlar, giderek daha karmaşık ve birbiriyle ilişkili bir dizi zorlukların üstesinden gelebilmesi daha dirençli ve dayanıklı ekonomik ve mekânsal politikalara ihtiyaç doğurmaktadır.

\section{SON NOTLAR}

$\mathrm{Bu}$ çalışma, KTÜN Lisansüstü Eğitim Enstitüsü, Şehir ve Bölge Pl. Anabilim Dalında tamamlanan "Yeni Bölgesel Gelişme Paradigmalarında Dirençli Mekânlar Olarak Kırsal Alanlar: Konya Beyşehir Kırsalında Bir Araştırma” başlıklı yüksek lisans tezinden yararlanılarak hazırlanmıștır.

\footnotetext{
Hakem Değerlendirmesi: Dış bağımsız.

Yazar Katkıları: Çalışma Konsepti/Tasarım- Ö.K., F.K.; Veri Toplama- F.K.; Veri Analizi/ Yorumlama- Ö.K., F.K.; Yazı Taslağı- Ö.K., F.K.; İçeriğin Eleştirel İncelemesi- Ö.K., F.K.; Son Onay ve Sorumluluk- Ö.K., F.K.

Çıkar Çatışması: Yazarlar çıkar çatışması bildirmemiştir.

Finansal Destek: Yazarlar bu çalışma için finansal destek almadığını beyan etmiştir.

Peer-review: Externally peer-reviewed.

Author Contributions: Conception/Design of Study- Ö.K., F.K.; Data Acquisition- F.K.; Data Analysis/Interpretation- Ö.K., F.K.; Drafting Manuscript- Ö.K., F.K.; Critical Revision of Manuscript- Ö.K., F.K.; Final Approval and Accountability- Ö.K., F.K.

Conflict of Interest: The authors have no conflict of interest to declare.

Grant Support: The authors declared that this study has received no financial support.
}

\section{KAYNAKÇA/REFERENCES}

Aköz, C. (2019). Beyşehir Gölü’nde Kuraklık Tehlikesi [Web log post]. Erişim Adresi: https://www.hurriyet.com.tr/yerel-haberler/konya/ beysehir-golunde-kuraklik-tehlikesi-41400156.

Allendorf, T., Smith, J., \& Anderson, D. (2007). Residents' perceptions of Royal Bardia National Park, Nepal. Landscape and Urban Planning, 82, 33-40.

Boschma, R., \& Martin, R. (2010). The aims and scope of evolutionary economic geography, R. Boschma ve R. Martin (Ed.), The handbook of evolutionary economic geography içinde (3-39). Northampton: Edward Elgar.

Bragagnolo, C, Pereira, M, \& Calado, H. (2016). Understanding and mapping local conflicts related to protected areas in small islands. Island Studies Journal, 11, 55-90.

Brown, C., Stevenson, J., Giovinazzi, S., Seville, E., \& Vargo, J. (2015). Factors influencing impacts on and recovery trends of organisations: evidence from the 2010/2011 Canterbury earthquakes. International 
Journal of Disaster Risk Reduction, 14, 56-72.

Cradock-Henry, N. (2017). New Zealand kiwifruit growers'vulnerability to climate and other stressors. Regional Environment Change, 17, 245-259.

Çolakkadıŏlu, D. (2012). Korunan alan yönetiminde katılımcılık: göreme tarihi milli parkı örneği, (Doktora Tezi). Çukurova Üniversitesi Fen Bilimleri Enstitüsü, Adana.

Demirayak, F. (2006). Türkiye'de korunan alanlar için yeni bir yaklaşım: ortaklaşa yönetim. (Doktora Tezi). Ankara Üniversitesi Sosyal Bilimler Enstitüsü, Ankara.

Eraydın, A. (2013). Bölgesel ekonomik uyum kapasitesi: Türkiye'deki bölgelerin ekonomik krizler ve sonrasındaki başarımlarını belirleyen etkenler. ODTÜ Gelişme Dergisi, 40, 179-208.

Fethi, F., İleri, Ö., Avc1, K. M. ve Kocadere, M. (2015). Eğirdir ve Beyşehir göllerinin uydu verileri ve topoğrafik harita yardımıyla kıyı çizgisi değişimleri. Doğal Kaynaklar ve Ekonomi Bülteni, 20, $37-45$.

Göktuğ, H. ve Arpa, N. (2016). Tekne turları kapsamında rekreasyonel taşıma kapasitesinin belirlenmesine yönelik bir yöntem yaklaşımı: Beyşehir Gölü Milli Parkı örneği. KSÜ Doğa Bilimleri Dergisi, 19, $15-27$.

Halfacree, K. (2006). Rural space: constructing a three-fold architecture. P. Cloke, T. Marsden ve P. Mooney (Ed.), Handbook of Rural Studies içinde (44-62). London: Sage.

Halfacree, K. H., \& Boyle, P. (1998). Migration, Rurality and the PostProductivist Countryside. London: Wiley and Sons Press.

Hassink, R., Klaerding, C., \& Marques, P. (2014). Advancing evolutionary economic geography by engaded pluralism. Regional Studies, 48, 1295-1307.

Heijman, W., Hagelaar, G., \& Heide, M. (2019). Rural resilience as a new development concept. EU Bioeconomy Economics and Policies II, 195-211.

Karakayacı, Ö. (2018). Bölge planlamada kırsal alanların önemini yeniden keşfetmek: yeni bölgecilik perspektifinde kuramsal tartışmalar. Planlama Dergisi, Ek sayl:1, 42-51.

Kepoğlu, A. ve Gülçubuk, B. (Eylül 2014). Tarımda araştırma, geliştirme ve inovasyon tarımsal kalkınmanın yeni ve yenilikçi araçlarından "Agroparklar, 11. Tarım Ekonomisi Kongresi, Samsun.

Kervankıran, İ. ve Eryılmaz, G. (2015). Milli parkların sürdürülebilir kullanımı ve yönetim planı önerisi: Isparta İli örneği. SDÜ Fen Edebiyat Fakültesi Sosyal Bilimler Dergisi, 34, 173-190.
Kuvan, Y., (Eylül 2005). Korunan alan yönetiminde etkinliğin önemi ve değerlendirilmesi. Korunan Doğal Alanlar Sempozyumu, Isparta

Ley, D. (1978). Social geography and social action. D. Ley ve M. Samuels (Ed.), Humanistic Geography: Prospects and Problems içinde (41-57). London: Croom Helm.

McDonagh, J. (2013). Rural geography I: Changing expectations and contradictions in the rural. Progress in Human Geography, 37, 712720.

MEVKA. (2014). Beyşehir İlçe Raporu [Web log post]. Erişim Adresi: Dsyqs4v1X719201730126PM.pdf (mevka.org.tr)

Mormont, M. (1987). Rural nature and urban natures. Sociologia Ruralis, 27, 3-20.

OECD. (2006). The new rural paradigm: policies and governance, Paris: OECD Publishing,

Ortiz-Guerrero, C. E. (2013). The new regionalism. Policy implications for rural regions. Cuadernos de Desarrollo Rural, 10, 47-67.

Pike, A., Dawley, S., \& Tomaney, J. (2010). Resilience, adaptation and adaptability, Cambridge Journal of Regions, Economy and Society, 3, 59-70.

Sabatino, M. (2019). Economic resilience and social capital of the Italian region. International Review of Economics and Finance, 61, 355-367.

Sánchez, P., Gallardo, R., \& Ceña-Delgado, F. (2014). Rural areas face the economic crisis: analyzing the determinants of successful territorial dynamics. Journal of Rural Studies, 35, 11-25.

Selfa, T., Fish, R., \& Winter, M. (2010). Farming livelihoods and landscapes: tensions in rural development and environmental regulation. Landscape Research, 35, 595-612.

Sietz, D., \& Feola, G., (2016). Resilience in the rural Andes: critical dynamics, constraints and emerging opportunities. Regional Environmental Change, 16, 2163-2169.

Spector, S., Cradock-Henry, N., Beaven, S., \& Orchiston, C. (2019). Characterising rural resilience in Aotearoa-New Zealand: a systematic review. Regional Environmental Change, 19, 543-557.

Tonts, M., Plummer, P., \& Argent N. (2014). Path dependence, resilience and the evolution of new rural economies: perspectives from rural Western Australia. Journal of Rural Studies, 36, 362-375.

Yalçın, F. (2016). Huğlu Av Tüfekleri Üretimi Saha Araştırması Raporu [Web log post]. Erişim Adresi: https://www.mevka.org.tr/Yukleme/ Uploads/Dsy2FnR8a719201744632PM.pdf

Yıldız, D. ve Atmış, E. (2019). Türkiye'nin korunan alanlarında çatışma analizi. Bartın Orman Fakültesi Dergisi, 21, 227-242. 
